
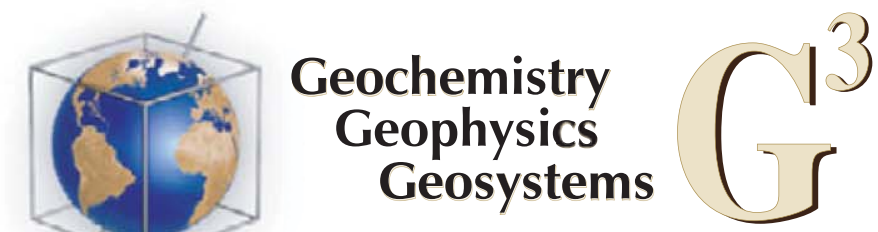

\title{
Diagenetic modulation of the magnetic properties in sediments from the Northern Indian Ocean
}

\author{
Alexandra Bouilloux and Jean-Pierre Valet \\ Institut de Physique du Globe de Paris, Université Paris Diderot, Sorbonne Paris-Cité, UMR 7154 CNRS, \\ 1 rue Jussieu, FR-75238 Paris CEDEX 05, France (valet@ipgp.fr)
}

\section{Franck Bassinot}

Laboratoire des Sciences du Climat et de l'Environnement (CEA-CNRS-UVSQ), Domaine du CNRS, Gif-sur-Yvette, France

\section{Jean-Louis Joron}

Institut de Physique du Globe de Paris, Université Paris Diderot, Sorbonne Paris-Cité, UMR 7154 CNRS, Paris, France

Sciences de la Terre, Laboratoire Pierre-Süe, CEA-Saclay, Gif-sur-Yvette, France

Marie-Madeleine Blanc-Valleron and Eva Moreno

Muséum National d'Histoire Naturelle, UMR CNRS 7207, Paris, France

\section{Fabien Dewilde}

Laboratoire des Sciences du Climat et de l'Environnement (CEA-CNRS-UVSQ), Domaine du CNRS,

Gif-sur-Yvette, France

\section{Myriam Kars}

Géosciences Montpellier UMR 5243, Université de Montpellier 2, Montpellier, France

\section{France Lagroix}

Institut de Physique du Globe de Paris, Université Paris Diderot, Sorbonne Paris-Cité, UMR 7154 CNRS, Paris, France

[1] Large changes in magnetic mineral concentration dependent parameters by more than 1 order of magnitude occur over $50-150 \mathrm{~cm}$ intervals in two marine sediment cores from the oxygen minimum zone in the Gulf of Aden. High-resolution sedimentological and chemical analyses indicate that these intervals are not associated with turbiditic events or sediment reworking, they do not result from changes in carbonate dilution or differences in sediment properties, and they do not correspond to volcanic layers. Magnetic mineralogical analyses reveal a change in magnetic mineral concentration from a magnetite-goethite assemblage to pure magnetite within the peak. The peaks almost disappear when the abundance of magnetic minerals is calculated after correcting for the magnetic moments of each magnetic mineral. Therefore, under the assumption that the variability of the magnetic parameters results from postdepositional mineralogical transformations, a relatively constant amount of magnetite was present at the surface of the sediment. Changes in redox conditions and nonsteady state diagenesis transformations have effectively been observed along both cores. Large values of total organic carbon coincide with poor preservation of biogenic and detrital magnetite, which reflects reductive dissolution of the finer magnetite grains. At the same levels, $\mathrm{Fe}^{2+}$ release from reductively dissolved magnetite favored precipitation of goethite. The susceptibility peaks coincide with episodes of magnetite preservation caused by reduced surface 
productivity and/or enhanced bottom-water ventilation accompanying northward extension of Glacial Antarctic Intermediate Water into the Indian Ocean.

Components : 11,697 words, 11 figures, 1 table.

Keywords : paleomagnetism; paleoenvironment; goethite; magnetite; Indian ocean.

Index Terms : 1512 Environmental magnetism: Geomagnetism and Paleomagnetism; 1540 Rock and mineral magnetism: Geomagnetism and Paleomagnetism; 1533 Remagnetization: Geomagnetism and Paleomagnetism; 1599 General or miscellaneous: Geomagnetism and Paleomagnetism.

Received 26 April 2013; Revised 15 July 2013; Accepted 26 July 2013; Published 23 September 2013.

Bouilloux, A., J.-P. Valet, F. Bassinot, J.-L. Joron, M.-M. Blanc-Valleron, E. Moreno, F. Dewilde, M. Kars, and F. Lagroix (2013), Diagenetic modulation of the magnetic properties in sediments from the Northern Indian Ocean, Geochem. Geophys. Geosyst., 14, 3779-3800, doi:10.1002/ggge.20234.

\section{Introduction}

[2] The evolution of magnetic susceptibility within a sediment column is frequently considered as a proxy for climatic changes [see, e.g., Robinson, 1986; Bloemendal et al., 1988, 1992; deMenocal et al., 1991; Meynadier et al., 1995; Lean and McCave, 1998; Haag, 2000]. The climatic imprint on susceptibility could result from dilution of the magnetic signal by nonmagnetic constituents. For example, an inverse relationship between magnetic mineral concentration and carbonate content is frequently observed in marine sedimentary records which can be indicative of climatic control through dilution of the magnetic signal within the carbonate matrix [Thompson and Oldfield, 1986; Robinson, 1986; Bloemendal et al., 1988, 1992; Meynadier et al., 1995; Lean and McCave, 1998; Haag, 2000]. However, in many cases, susceptibility variations remain unchanged after correcting for carbonate dilution. Thus, magnetic susceptibility carries an intrinsic signal, which is likely to differ between sites and could be caused by changes in concentration, grain size, and magnetic mineralogy, which is dependent on the nature of the magnetic particles.

[3] The present paper focuses on the study of sediment cores MD92-1002 and MD92-1003 from the Northern Indian Ocean (Gulf of Aden), which are both characterized by abrupt and highamplitude magnetic susceptibility peaks during glacial periods (subsequently referred to as the M1-M3 peaks). Such high-amplitude peaks (up to a factor of 20 in amplitude) are puzzling because susceptibility changes in marine sediments rarely exceed a factor of 3 or 4 in amplitude (except in the presence of significant volcanic ash layers). Even the amplitude of susceptibility variations associated with Northern Atlantic Heinrich layers, which reflect severe sedimentary changes resulting from abrupt paleoclimatic events, rarely reach this level [Thouveny et al., 2000; Stanford et al., 2011].

[4] We performed high-resolution studies of magnetic and geochemical analyses of both cores in order to determine which factors were responsible for generating the $\mathrm{M}$ peaks in the Gulf of Aden and how they were related to paleoenvironmental conditions. The present study is also aimed at discussing various concepts concerning the origin of magnetic susceptibility variations in sediments.

\section{Hydrographic/Climatic Settings and Sedimentary Material}

[5] Sedimentation in the Gulf of Aden is characterized by eolian transport of dust particles [Sirocko et al., 1993; Leuschner and Sirocko, 2000; Stein et al., 2007], and by a strong monsoon imprint on marine pelagic production through seasonal modulation of the Northern Indian Ocean upwelling systems [Sirocko et al., 1993]. The Gulf of Aden is also located near the Afar depression, in which extensive volcanic activity has occurred. In order to study late Quaternary sedimentation in this area, cores MD92-1002 $\left(12^{\circ} 01.32^{\prime} \mathrm{N}\right.$, $44^{\circ} 12.02^{\prime} \mathrm{E}$, core length: $9.42 \mathrm{~m} ; 1327 \mathrm{~m}$ water depth) and MD92-1003 $\left(11^{\circ} 49.50^{\prime} \mathrm{N}, 43^{\circ} 46.60^{\prime} \mathrm{E}\right.$, core length: $12.82 \mathrm{~m}, 485 \mathrm{~m}$ water depth) were collected in 1992 by the R/V Marion-Dufresne during the MD73 REDSED cruise. They are 


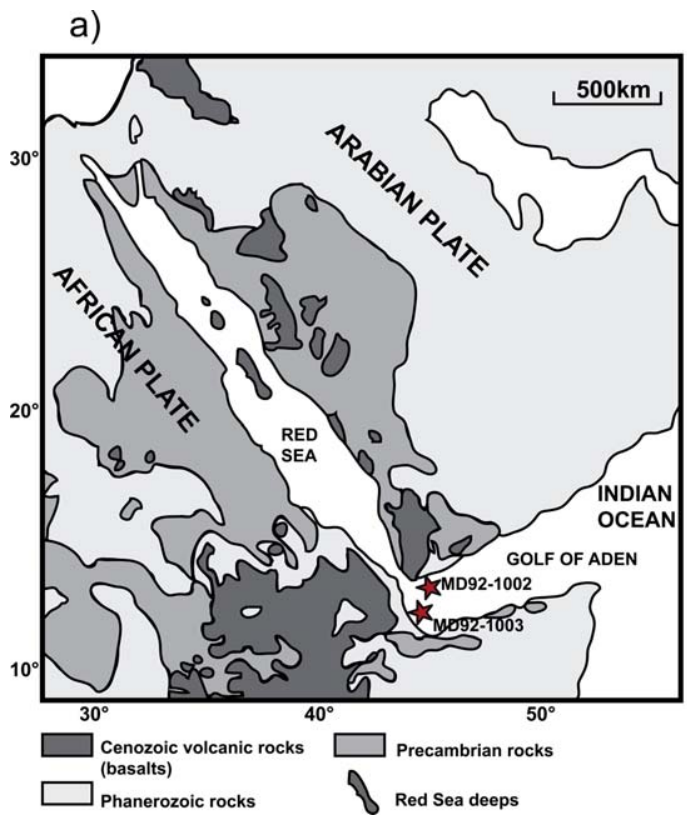

b)

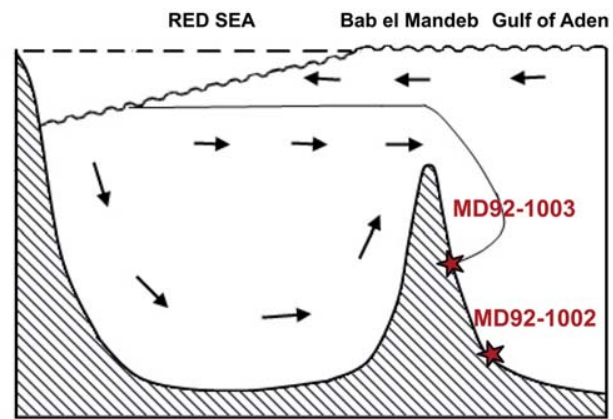

Figure 1. Location map and bathymetric profile modified after Stein et al. [2007] with the position of the two studied cores MD92-1002 and MD92-1003 in the Gulf of Aden (Northern Indian Ocean).

located on the eastern and western sides of the Strait of Bab-el-Mandeb, respectively (Figure 1), and are bathed by bottom waters with low oxygen content, which result from the strong export productivity in the Arabian Sea and its insufficient ventilation [van Weering et al., 1997].

[6] The lithology of both cores is homogeneous and is dominated by green calcareous clay with pyrite and shell fragments (pteropods, lamellibranches). The low-field magnetic susceptibility $(k)$ was measured every $2 \mathrm{~cm}$ above the sediment surface with a Bartington susceptibility meter coupled to a MS2E sensor. Despite the apparent homogeneity of the sediment, the down-core $k$ profile for MD92-1002 is characterized by a large peak (subsequently referred to as M1), between 700 and $850 \mathrm{~cm}$, with an amplitude that varies by more than a factor of 20 compared to the rest of the core (Figure 2a). Smear slide examinations reveal the presence of a few glass shards, disseminated over a $\sim 15 \mathrm{~cm}$ interval in the lower part of the $150 \mathrm{~cm}$ thick, M1 susceptibility peak. Similarly, susceptibility measurements performed on core MD921003 (Figure 2b) indicate the presence of two highamplitude peaks (referred to as M2 and M3) between 251-291 $\mathrm{cm}$ and 789-817 cm, respectively, where $k$

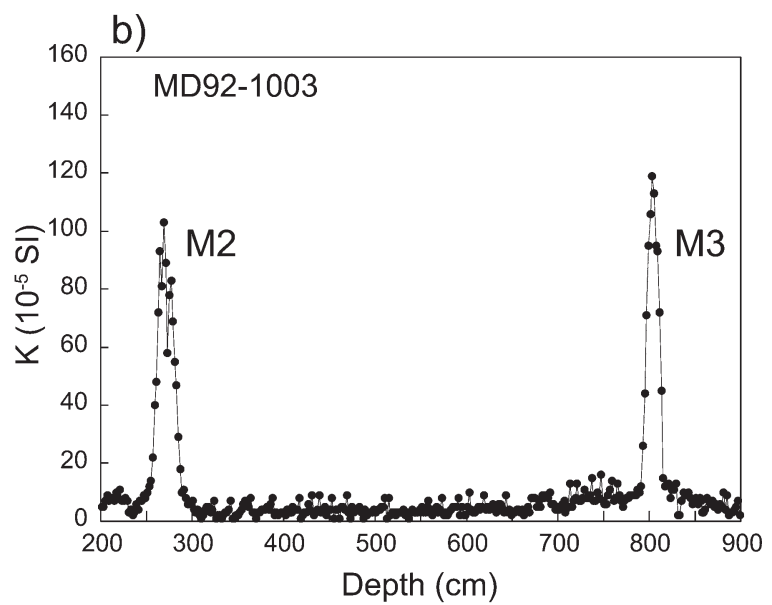

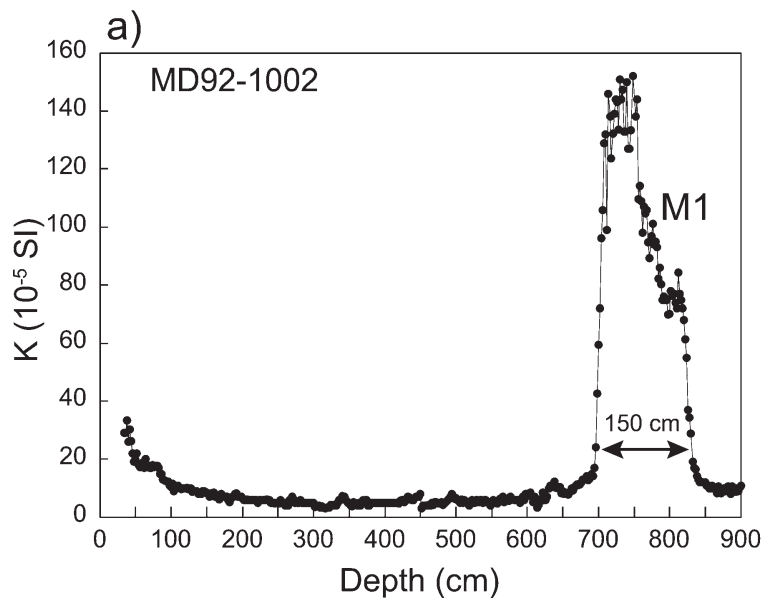

Figure 2. Down-core profiles of magnetic susceptibility for (a) core MD92-1002 and (b) core MD92-1003 as a function of depth. The M1-M3 labels indicate the susceptibility peaks. 
Table 1. AMS ${ }^{14} \mathrm{C}$ Dates of Core MD92-1002 From the Northern Indian Ocean

\begin{tabular}{|c|c|c|c|c|c|}
\hline Sample Code & $\begin{array}{l}\text { Sampling } \\
\text { Depth }(\mathrm{cm})\end{array}$ & Radiocarbon Laboratory & $\begin{array}{l}\text { Sample } \\
\text { Reference }\end{array}$ & $\begin{array}{c}\text { AMS }{ }^{14} \mathrm{C} \\
\text { Age }\left(\left({ }^{14} \mathrm{C} \text { yr BP }\right)\right.\end{array}$ & $\begin{array}{l}\text { Calibrated Age } \\
\text { (Cal yr BP) }\end{array}$ \\
\hline MD92-1002/I-5 cm & 5 & $\begin{array}{l}\text { Laboratoire de Mesures } \\
\text { Carbone } 14 \text { UMS } 2572\end{array}$ & SacA 8283 & $820 \pm 30$ & $304 \pm 160$ \\
\hline MD92-1002/I-39.5 cm & 39.5 & $\begin{array}{l}\text { Laboratoire de Mesures } \\
\text { Carbone } 14 \text { UMS } 2572\end{array}$ & SacA 22731 & $1045 \pm 40$ & $498 \pm 168$ \\
\hline MD92-1002/II-3 cm & 152 & $\begin{array}{l}\text { Laboratoire de Mesures } \\
\quad \text { Carbone } 14 \text { UMS } 2572\end{array}$ & SacA 8284 & $3015 \pm 30$ & $2593 \pm 160$ \\
\hline MD92-1002/II-72.5 cm & 221.5 & $\begin{array}{l}\text { Laboratoire de Mesures } \\
\text { Carbone } 14 \text { UMS } 2572\end{array}$ & SacA 8285 & $4235 \pm 30$ & $4111 \pm 160$ \\
\hline MD92-1002/III-7.5 cm & 306.5 & $\begin{array}{l}\text { Laboratoire de Mesures } \\
\text { Carbone } 14 \text { UMS } 2572\end{array}$ & SacA 8286 & $6265 \pm 35$ & $6531 \pm 164$ \\
\hline MD92-1002/III-108.5 cm & 407.5 & $\begin{array}{l}\text { Laboratoire de Mesures } \\
\text { Carbone } 14 \text { UMS } 2572\end{array}$ & SacA 8287 & $9475 \pm 40$ & $10,145 \pm 168$ \\
\hline MD92-1002/IV-57.75 cm & 507.5 & $\begin{array}{l}\text { Laboratoire de Mesures } \\
\text { Carbone } 14 \text { UMS } 2572\end{array}$ & SacA 24462 & $10,450 \pm 40$ & $11,297 \pm 168$ \\
\hline MD92-1002/V-22.75 cm & 622.75 & $\begin{array}{l}\text { Laboratoire de Mesures } \\
\text { Carbone } 14 \text { UMS } 2572\end{array}$ & SacA 24463 & $11,760 \pm 45$ & $13,082 \pm 173$ \\
\hline MD92-1002/V-77.5 $\mathrm{cm}^{\mathrm{a}}$ & 677.5 & $\begin{array}{l}\text { Laboratoire de Mesures } \\
\text { Carbone } 14 \text { UMS } 2572\end{array}$ & SacA 22732 & $13,000 \pm 50$ & $14,525 \pm 179$ \\
\hline MD92-1002/VI-84 $\mathrm{cm}^{\mathrm{a}}$ & 834 & $\begin{array}{l}\text { Laboratoire de Mesures } \\
\text { Carbone } 14 \text { UMS } 2572\end{array}$ & SacA 22733 & $14,910 \pm 60$ & $17,439 \pm 191$ \\
\hline
\end{tabular}

${ }^{\mathrm{a}} \mathrm{AMS}{ }^{14} \mathrm{C}$ on mixing $G$. ruber white and G. sacculifer, for other samples only on G. ruber white. Calibrated ages are indicated with 2 sigma error.

increases by a factor of 20 . The oldest M3 peak has values as large as $119 \times 10^{-5} \mathrm{SI}$, while the younger one (M2) culminates at $100 \times 10^{-5} \mathrm{SI}$.

[7] There is no visible sharp boundary at the bottom of these high-amplitude susceptibility peaks, which could suggest turbiditic events or sediment reworking. The rest of the sediment is characterized by low susceptibility without significant variations. In order to conduct detailed studies of both cores and to understand the nature of these high-amplitude susceptibility peaks, discrete samples were taken at an average spatial resolution of $\sim 5 \mathrm{~cm}$ for stable isotopic stratigraphy, sedimentological, and geochemical analyses. For magnetic property analyses, sediment from core MD92-1002 was sampled using U-channels [Nagy and Valet, 1993; Weeks et al., 1993] within the $1.5 \mathrm{~m}$ long working halves, while plastic cubes were taken from core MD92-1003 (no U-channel). The upper $2 \mathrm{~m}$ of core MD92-1003 were affected by coring disturbances and therefore, are not considered in this study.

\section{Stratigraphy and Age Models}

[8] Oxygen and carbon isotopic records $\left(\delta^{18} \mathrm{O}\right.$ and $\delta^{13} \mathrm{C}$, expressed in \%o versus Vienna Peedee belemnite) from surface-dwelling planktonic foraminifera Globigerinoides ruber (picked in the narrow $250-315 \mu \mathrm{m}$ size fraction) were obtained from 154 samples from core MD92-1002 and 149 samples for core MD92-1003, with an average spatial resolution of $5 \mathrm{~cm}$. The mean external reproducibility $(1 \sigma)$ is $\pm 0.05 \%$ for $\delta^{18} \mathrm{O}$ and $\pm 0.03 \%$ for $\delta^{13} \mathrm{C}$.

[9] The $\delta^{18} \mathrm{O}$ stratigraphy reveals that core MD92-1002 contains an expanded Holocene section $(\sim 400 \mathrm{~cm})$ that reaches the Last Glacial Maximum (LGM). The precise age model of MD921002 is based on 10 accelerator mass spectrometry ${ }^{14} \mathrm{C}$ dates (Table 1) obtained on shells from two shallow-dwelling planktonic foraminifera species G. ruber and Globigerinoides sacculifer (measurements were performed at the Laboratoire de Mesures Carbone 14, LMC14, Saclay, France). The ${ }^{14} \mathrm{C}$ dates were converted to calendar ages using the CALIB6.O software [Stuiver and Reimer, 1993] and the 2009 marine calibration curve [Reimer et al., 2009]. We assumed a global surface reservoir age of 400 years and a regional correction $\Delta r=163 \pm 74$ years [Southon et al., 2002]. The average $5 \mathrm{~cm}$ sampling resolution translates into an average temporal resolution of $\sim 120$ years. The $\delta^{18} \mathrm{O}$ record for core MD92-1002 is plotted versus age in Figure $3 \mathrm{a}$, while an age versus depth plot is shown in Figure 3c. As shown in Figures $3 \mathrm{a}$ and $3 \mathrm{c}$, there is no evidence of hiatuses, nor is there any visible disturbance of the isotopic stratigraphy. Core MD92-1002 seems to contain a continuous and undisturbed sequence from the LGM ( $\sim 20 \mathrm{ka} \mathrm{BP})$ to the late Holocene. The mean sedimentation rate is $\sim 52 \mathrm{~cm} / \mathrm{ka}$, with the highest rate $(90 \mathrm{~cm} / \mathrm{ka})$ observed during the deglaciation, at the beginning of the Younger Dryas interval. Within this age model, the susceptibility event M1 spanning the depth 

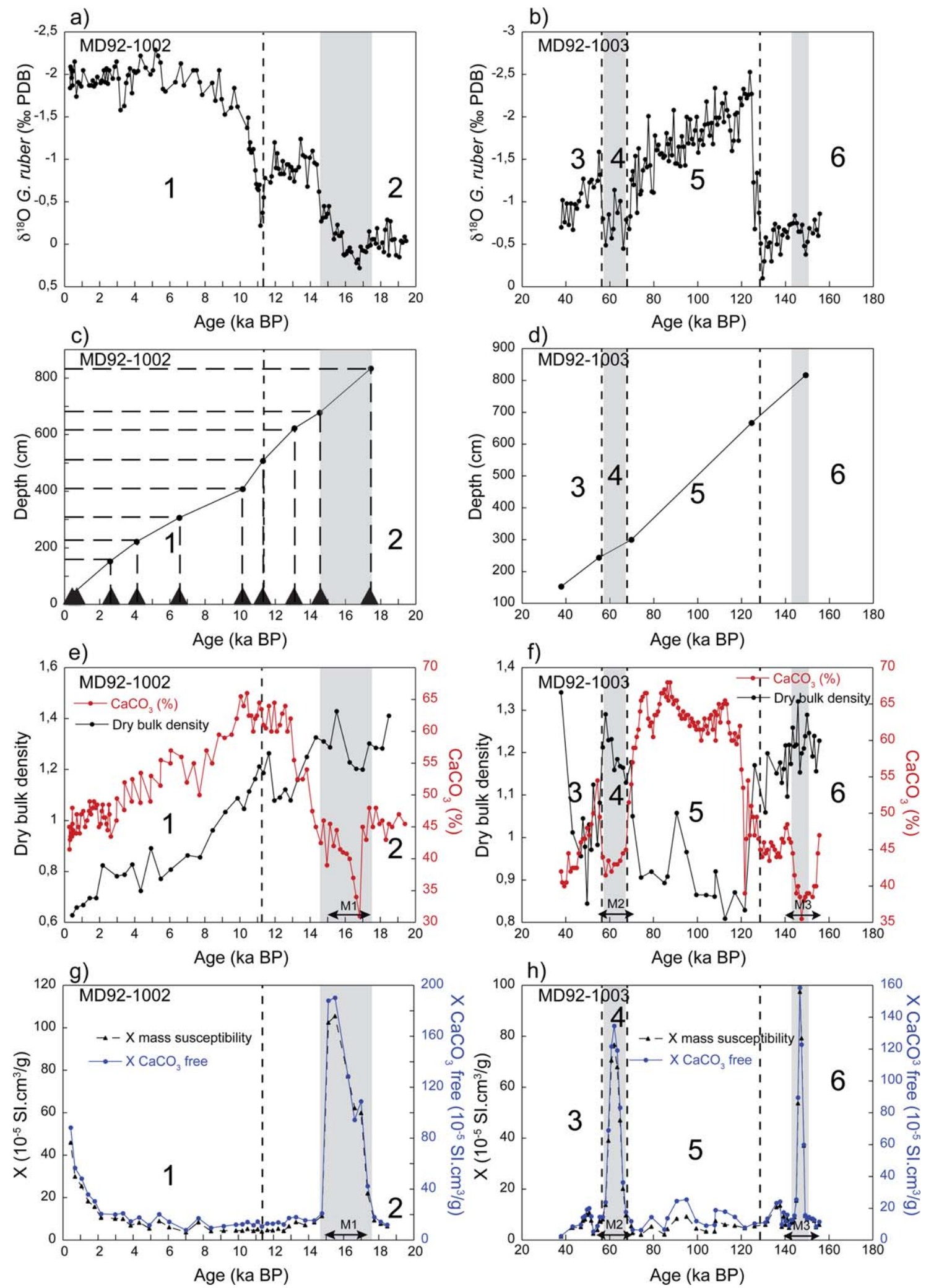

Figure 3. Oxygen isotope stratigraphy and depth-age profiles for cores (a and c) MD92-1002 and (b and d) MD92-1003 from the Gulf of Aden, Northern Indian Ocean. Numbers refer to the isotope stages of Emiliani [1955] and triangles to the AMS ${ }^{14} \mathrm{C}$ dates. (e and $\mathrm{f}$ ) Carbonate content and dry bulk density as a function of age for cores MD92-1002 and MD92-1003, respectively. ( $g$ and h) Magnetic susceptibility after correcting for density variations and carbonate dilution. 
interval $700-850 \mathrm{~cm}$ is dated from $\sim 15$ to $\sim 17.5$ Cal ka BP.

[10] The $\delta^{18} \mathrm{O}$ record for core MD92-1003 is plotted versus age in Figure $3 \mathrm{~b}$. The age model for core MD92-1003 is based on visual correlation of large amplitude $\delta^{18} \mathrm{O}$ shifts (e.g., transitions of marine isotope stage (MIS) 6 to MIS 5, and MIS 5/MIS 4) to their counterparts in the astronomically tuned, lowlatitude stack of Bassinot et al. [1994] using the Analyseries 2.0.4.2 software [Paillard et al., 1996]. Ages were linearly interpolated between the selected tie points, assuming constant sedimentation rates within each successive interval (Figure 3d). Core MD921003 goes back to the MIS 6 (160 ka), with an average time resolution of $\sim 1 \mathrm{ka}$. It has a disturbed upper section, which encompass the LGM and Holocene. This low-resolution age model indicates that the M2 and M3 peaks located at 269 and $802 \mathrm{~cm}$ have ages of $\sim 60$ and $\sim 150 \mathrm{ka} \mathrm{BP}$, respectively.

\section{Paleomagnetic Directions}

[11] The natural remanent magnetization (NRM) of U-channel samples from core MD92-1002 was measured at $2 \mathrm{~cm}$ intervals with a $2 \mathrm{G}$ Enterprises pass-through superconducting rock magnetometer in the shielded room of Institut de Physique du Globe de Paris (IPGP) using the protocol described by Nagy and Valet [1993]. Stepwise demagnetization was performed every $5 \mathrm{mT}$ from 5 to $30 \mathrm{mT}$ and then every 10 up to $60 \mathrm{mT}$. No directional measurement was performed for core MD92-1003. Typical demagnetization diagrams obtained at specific levels from core MD92-1002 are shown in Figure S1, supporting material. ${ }^{1}$ In many cases, a small viscous overprint was removed after 25 or $30 \mathrm{mT}$, while complete demagnetization was usually attained between 50 and $60 \mathrm{mT}$. The characteristic directions were isolated using the Paleomac 6.2 software [Cogné, 2003] by fitting straight lines through the data and through the origin of the demagnetization diagrams.

[12] The successive declinations and inclinations for core MD92-1002 are plotted as a function of age in Figure S2 and S3, supporting material. Core MD92-1002 was twisted during coring and the declination was corrected using a simple linear regression. In the absence of orientation within the horizontal plane, the mean declination value for

\footnotetext{
${ }^{1}$ Additional supporting information may be found in the online version of this article.
}

the entire core was set to the zero. This assumption is justified by the fact that the sediment covers a time period exceeding beyond $10 \mathrm{ka} \mathrm{BP}$, and therefore, the time-averaged nondipole field should be negligible. The upper part of the core has high water contents and was disturbed by coring. Paleomagnetic directions in the studied intervals are variable, particularly in inclination. The mean inclination of $25.5^{\circ}$ is $2.5^{\circ}$ steeper than that of the geocentric axial dipole at the site latitude.

[13] The amplitude and timing of declination and inclination changes in core MD92-1002 within the M1 peak indicate that this interval is not linked to any perturbation of the sediment. The NRM data confirm, therefore, the conclusions regarding the quality of core MD92-1002, which were drawn from visual inspection, from the $\delta^{18} \mathrm{O}$ record and from the AMS ${ }^{14} \mathrm{C}$ age model. In the absence of a paleomagnetic directional record, it is more difficult to draw similar conclusions for core MD921003 , but the similar magnetic properties between the two cores and the lack of apparent disturbance in the $\delta^{18} \mathrm{O}$ curve over the MIS 3-MIS 6 stratigraphic interval suggest that core MD92-1003 also provides a good quality, upper Quaternary record.

\section{Magnetic Mineral Concentration, Density, and Carbonate Content}

[14] Our volume magnetic susceptibility measurements will depend to some extent on the porosity of the sedimentary material. In order to explore the role of index property changes on the susceptibility peaks, measurements of wet and dry bulk densities (mainly controlled by porosity in marine sediments) were made for 107 samples (41 from core MD92-1002 and 66 from core MD92-1003). Results are shown in Figures 3e and 3f. Susceptibility values associated with density measurements at the same stratigraphic levels were converted to equivalent values of specific magnetic susceptibility to compensate for density variations. After correction, the susceptibility peaks remained almost unchanged in both records (Figures $3 \mathrm{~g}$ and $3 \mathrm{~h}$ ).

[15] Magnetic susceptibility and other rock magnetic parameters can be highly dependent upon changes in dilution by the carbonate matrix, which should be corrected. The carbonate content (in wt $\%$ ) of 116 samples from core MD92-1002 and 152 samples from core MD92-1003 was therefore determined at the Museum National d'Histoire Naturelle (Paris) by measuring the $\mathrm{CO}_{2}$ released by reacting 
$100 \mathrm{mg}$ of finely ground, bulk sediment powder with $0.4 \mathrm{~cm}^{3}$ of $8 \mathrm{~N} \mathrm{HCl}$ in a carbonate bomb (uncertainty $\sim 1 \%$ ). The total $\mathrm{CaCO}_{3}$ content varies from 30 to $65 \%$ in core MD92-1002 and from 35 to $70 \%$ in core MD92-1003 (Figures 3e and 3f). Carbonate content is lower during glacial periods with a particularly clear minimum at $\sim 17 \mathrm{Cal} \mathrm{ka} \mathrm{BP}$ in core MD92-1002. It is usual to account for the influence of carbonate content on magnetic concentration by the simple linear correction $C_{\mathrm{mag}} \mathrm{nc}(\%)=C_{\mathrm{mag}} /$ $\left(1-\mathrm{CaCO}_{3}\right)$, where $C_{\mathrm{mag}}$ is the magnetic concentration and $C_{\mathrm{mag}}$ nc is the magnetic mineral concentration corrected for the dilution effect (i.e., noncarbonated). After applying this technique to the specific magnetic susceptibility records from cores MD92-1002 and MD92-1003, we found the same pattern of variations before and after correction (Figures $3 \mathrm{~g}$ and $3 \mathrm{~h}$ ). This was expected given the relatively small amplitude of $\mathrm{CaCO}_{3}$ changes compared to those of the susceptibility records. We infer, therefore, that the M peaks do not result from carbonate dilution.

[16] The NRM intensity was scrutinized in order to investigate variations in magnetic particles concentration and/or changes in magnetic mineralogy. The variations of NRM at $20 \mathrm{mT}$ as a function of age for core MD92-1002 (Figure S4, supporting material) are characterized by a large amplitude peak between $\sim 15$ and $17.5 \mathrm{Cal} \mathrm{ka} \mathrm{BP}$, which corresponds to the M1 susceptibility peak. We have investigated whether the magnetization of smaller magnetic particles give rise to the same kind of variations. Anhysteretic remanent magnetization (ARM) was imparted in a $30 \mu \mathrm{T}$ steady field in the presence of a $100 \mathrm{mT}$ peak alternating field at 2 $\mathrm{cm}$ stratigraphic intervals in core MD92-1002 and was subsequently demagnetized at $20 \mathrm{mT}\left(\mathrm{ARM}_{20}\right.$ $\mathrm{mT}$ ) for direct comparison with the $\mathrm{NRM}_{20 \mathrm{mT}}$. The M1 peak is also present in the $\mathrm{ARM}_{20 \mathrm{mT}}$ record (Figure S5, supporting material) with similar amplitude as the other rock magnetic parameters.

[17] The down-core relative variations in magnetic grain sizes could be approximated by the $\mathrm{ARM} / K$ ratio provided that the magnetic mineralogy is entirely dominated by magnetite. We will see below that this is not the case and therefore that such estimates would be meaningless.

[18] In summary, cores MD92-1002 and MD921003 are characterized by large amplitude and abrupt susceptibility peaks (M1-M3), in which $k$ increases by a factor of 20 with respect to the average background signal. They occur at $15-17 \mathrm{Cal}$ $\mathrm{ka}$ BP in core MD92-1002 (M1) and at $60 \mathrm{ka}$ BP and $150 \mathrm{ka}$ BP (M2 and M3) in core MD92-1003. These peaks are neither associated with major sediment reworkings nor with turbidite events. They do not correspond to changes in density/porosity of the sediments, nor do they result from carbonate dilution. They are present in all magnetic parameters (NRM, $k, A R M$ ) and are caused, therefore, by changes in the magnetic material concentration or reflect an evolution in magnetic mineralogy. Before exploring these possibilities we investigate the possible input of volcanic material.

\section{Trace Elements : Origin and Evolution of Sedimentary Material}

[19] Despite the fact that no ash layer was macroscopically observed in cores MD92-1002 and MD92-1003, we could not totally reject the possibility that the large amplitude susceptibility peaks could be related to enhanced supply of volcanic material from the Afar area (considering that a few disseminated glass shards were detected by smear slide examination in the lower part of the M1 interval). We used neutron activation to analyze changes in the elemental composition of the bulk sediment. The measurements were performed at the Pierre Sue Laboratory (CEA, Saclay) on 106 samples from core MD92-1002 and 101 samples from core MD92-1003, most of which were taken at a high sampling resolution (down to $1 \mathrm{~cm}$ ) across the $\mathrm{M}$ susceptibility peaks. Following the technique described in Joron et al. [1997], $150 \mathrm{mg}$ aliquots of finely powdered sediment were weighed and wrapped in aluminum foil. The samples were then irradiated under an epithermal neutron flux in the core of the Osiris reactor. We only discuss here the most pertinent results derived from these experiments.

[20] A significant thorium anomaly in core MD92-1002 coincides with the $15 \mathrm{~cm}$ thick glass layer identified by smear slide analysis, while this element remains stable in core MD92-1003 (Figures $4 \mathrm{a}$ and $4 \mathrm{~b}$ ). The ratio of elements with similar lithophile characters can be used to characterize the source of the detrital fraction. The evolution of the thorium to tantalium $(\mathrm{Th} / \mathrm{Ta})$ ratio versus the tantalium to hafnium $(\mathrm{Ta} / \mathrm{Hf})$ ratio indicates the presence of two distinct sources in core MD921002 (Figure 4e). The first noticeable chemical signature corresponds to the volcanic signature of the short volcanic event at $\sim 17 \mathrm{Cal}$ ka BP, while the second one is due to bulk sediment composition. By contrast, $\mathrm{Th} / \mathrm{Ta}$ versus $\mathrm{Ta} / \mathrm{Hf}$ results indicate a single set of chemical composition along 
a)
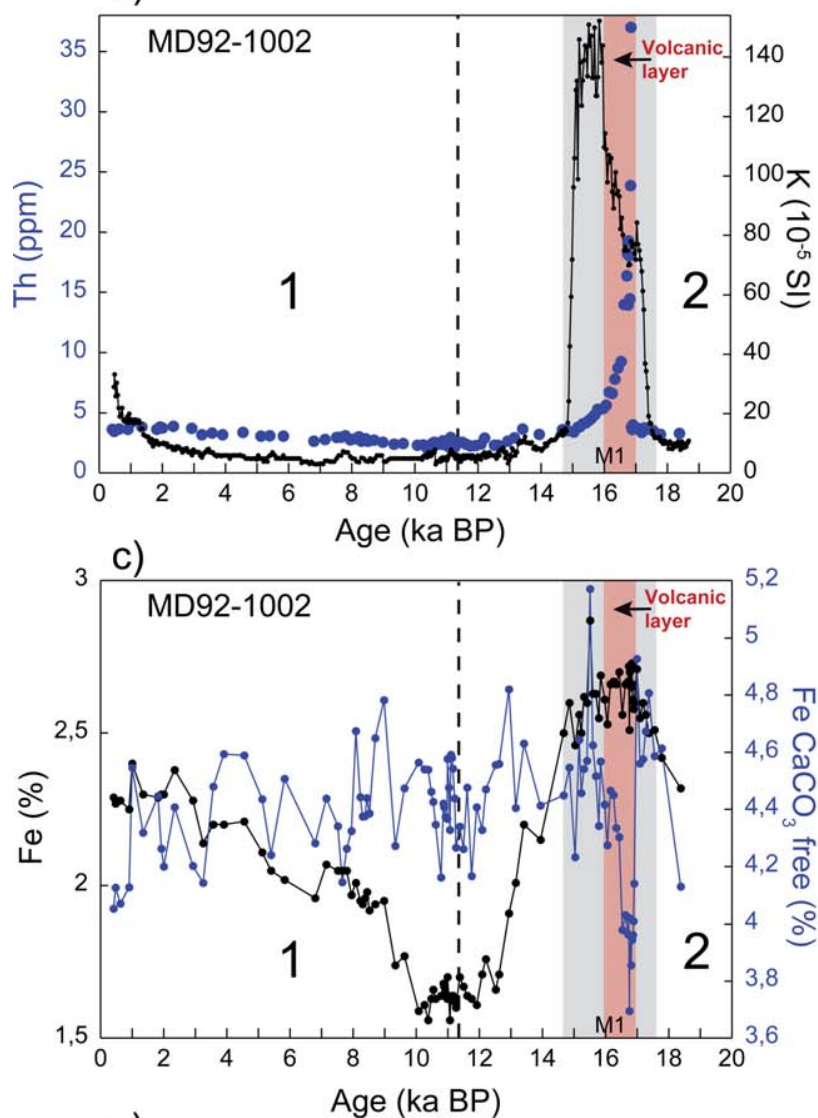

e)

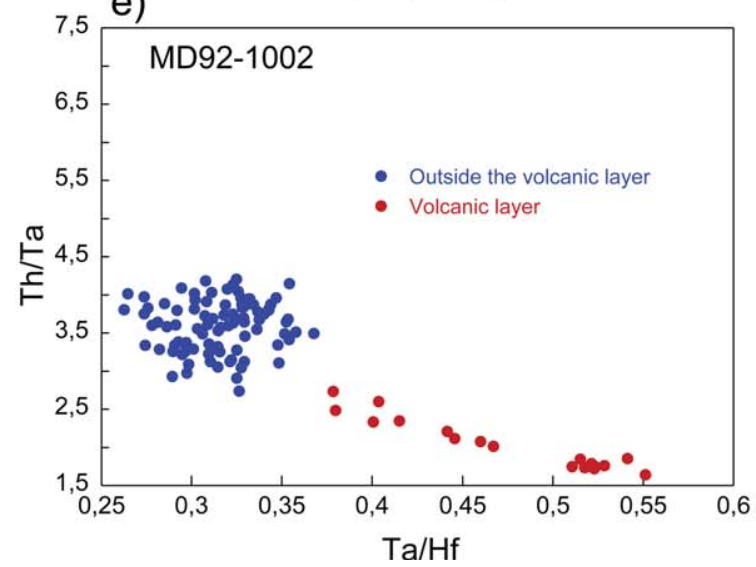

b)
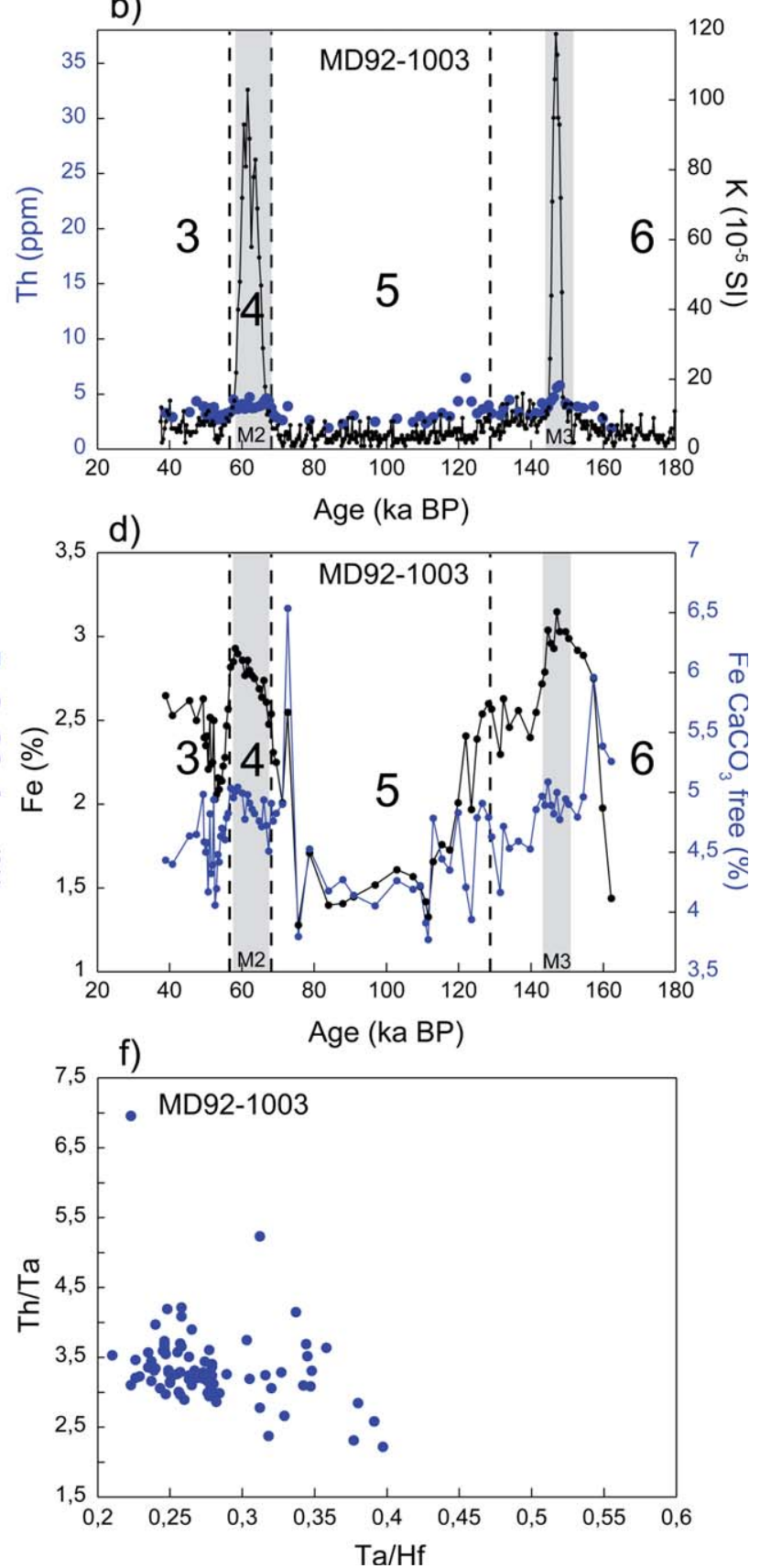

Figure 4. (a and b) Down-core variations of thorium concentration in cores MD92-1002 and MD92-1003. A thin volcanic ash layer is clearly visible in core MD92-1002 (red). (c and d) Iron content (black curve) and carbonate-free iron (blue curve). (e and f) The Th/Ta against $\mathrm{Ta} / \mathrm{Hf}$ plot does not indicate any change in the sediment source. The ash layer from core MD92-1002 has a distinct signature (red dots).

core MD92-1003, which points to the absence of significant additional or exotic sediment sources in this case (Figure 4f). The values for core MD921003 fall within the same range as for the bulk sediment from core MD92-1002.

[21] The M1 peak in magnetic mineral concentration is about $150 \mathrm{~cm}$ thick (extending from 700 to
$850 \mathrm{~cm})$; it is much thicker, therefore, than the Th anomaly peak (peak volcanic material: 790-802 $\mathrm{cm}$; mixing zone: 745-785 cm). This suggests that the entire M1 peak, whose age is well constrained between 15 and $17.5 \mathrm{Cal}$ ka BP, does not correspond to a massive volcanic episode. The Th profile indicates that a short volcanic event coincidently occurred at the onset of M1 but is not 
responsible for the overall susceptibility peak. The conclusion that the three major susceptibility peaks are not related to volcanic activity is reinforced by the absence of a volcanic signature in the M2 and M3 peaks from core MD92-1003.

[22] Iron is a key element in relation to magnetic properties. The highest values of Fe obtained by neutron activation occur within the 15-18 Cal ka BP interval in core MD92-1002 (Figure 4c), whereas the lowest values occur between 10 and $13 \mathrm{Cal} \mathrm{ka}$ BP. The iron content of core MD921003 reaches maxima during MIS 4 and 6 (around 60 and $150 \mathrm{ka} \mathrm{BP}$ ), but there is no evidence for a sharp and large amplitude increase during the $\mathrm{M}$ peaks (Figure 4d). In both cores, changes in iron content appear to be somewhat opposite to those of the carbonate content. As for the susceptibility, we checked, therefore, whether the iron content was modulated by carbonate dilution. Contrary to observations for magnetic susceptibility, the amplitude of $\mathrm{Fe}$ variations considerably decreased in both cores after correction for $\mathrm{CaCO}_{3}$ content, except at $\sim 17 \mathrm{Cal}$ ka BP in core MD92-1002, which corresponds to the thin glass layer. $\mathrm{CaCO}_{3}$ correction also reveals an oscillating trend between 2 and 2.5\% in core MD92-1002 (Figure 4c), which is not so clear in core MD92-1003 likely because of its lower resolution (Figure 4d). These results point out the difference in behavior between the total $\mathrm{Fe}$ content and the concentration of magnetic iron oxides (as indicated by $k, N R M$, and ARM). Down-core Fe variations are mainly controlled by changes in carbonate content (dilution effect) and appear to be decoupled from variations in magnetic parameters. This suggests that $\mathrm{Fe}$ content is controlled by clay minerals, while the magnetic iron oxides control the large amplitude changes in magnetic parameters.

\section{Magnetic Mineralogy Variations}

[23] Saturation magnetization can differ by a factor of 200 between magnetic minerals (e.g., magnetite and hematite) [O'Reilly, 1984]. Consequently, relative changes in magnetic mineralogy can induce large variations in rock magnetic parameters. Several indicators are commonly used to document the down-core evolution of magnetic minerals. A first useful approach is to rely on the ratio between lowand high-coercivity minerals, which is efficiently described by the $S$ ratio [Bloemendal et al., 1992]. We estimated the $S$ ratio for 84 discrete samples from core MD92-1002 and 169 samples from core MD92-1003. The samples were given an isothermal remanent magnetization (IRM) in a direct field of $1 \mathrm{~T}$ before being measured, subsequently remagnetized in a reverse field of $0.3 \mathrm{~T}$ and then remeasured. The $S$ ratio was calculated according to the formula of Bloemendal et al. [1992].

[24] The $S$ ratio (Figures 5a and 5b) values within the $\mathrm{M}$ peaks are close to 1 and are associated with a low-coercivity mineral, most likely magnetite. The other levels have lower values (circa 0.8), which are indicative of a large amount of highcoercivity minerals (e.g., goethite and hematite), which is supported by IRM acquisition analysis imparted from 0.05 to $1.2 \mathrm{~T}$ in an electromagnet. The experiment was conducted on 12 discrete samples for core MD92-1002 and 8 samples for core MD92-1003 located within and outside the magnetic peaks. The IRM acquisition curves are consistent with $S$ ratio value (Figure 5d) and point to the existence of two mineral families in samples from outside the peaks, while a single, lowcoercivity material dominates within the peaks.

[25] The $\left(\mathrm{NRM}_{20}-\mathrm{NRM}_{60}\right) / \mathrm{NRM}_{20}$ ratio (hereafter referred as the $R$ ratio) is another pertinent indicator of the coercivity of remanence since it reveals the amount of magnetization remaining after a specific demagnetization step (here we selected $60 \mathrm{mT}$, which is higher than the coercivity of remanence for most magnetite grains). Thus, down-core changes of $R$ should be in phase with the $S$ ratio because a magnetically soft component is characterized by a large $S$ ratio, while a large $R$ is caused by low resistance to alternating field demagnetization and removal of a large part of the magnetization. All analyses indicate that this is the case (Figures 5c and 5d), and that changes in remanence intensity are linked, therefore, to changes in magnetic mineralogy. The presence of magnetite is detected rapidly from its Curie temperature (Figures 5e and 5f).

[26] Temperature dependence of magnetic susceptibility curves, $k=f(T)$, was measured by heating small powdered sediment samples using a Kappabridge system (KLY2-CS2) between 50 and $700^{\circ} \mathrm{C}$. All 13 analyzed samples ( 7 for core MD92-1002 and 6 for core MD92-1003) produced irreversible heating and cooling curves. A dominant feature is the absence of hematite in the samples taken just below the M1 peak in core MD92-1002 (850 cm; 17.7 Cal ka BP; Figure 5e) and outside the M2 peak in core MD92-1003 (226 $\mathrm{cm}$; Cal $51.5 \mathrm{ka} \mathrm{BP}$; Figure 5f). The absence of magnetization loss between $280^{\circ} \mathrm{C}$ and $400^{\circ} \mathrm{C}$ also indicates the absence of greigite [Roberts, 1995]. 
a)

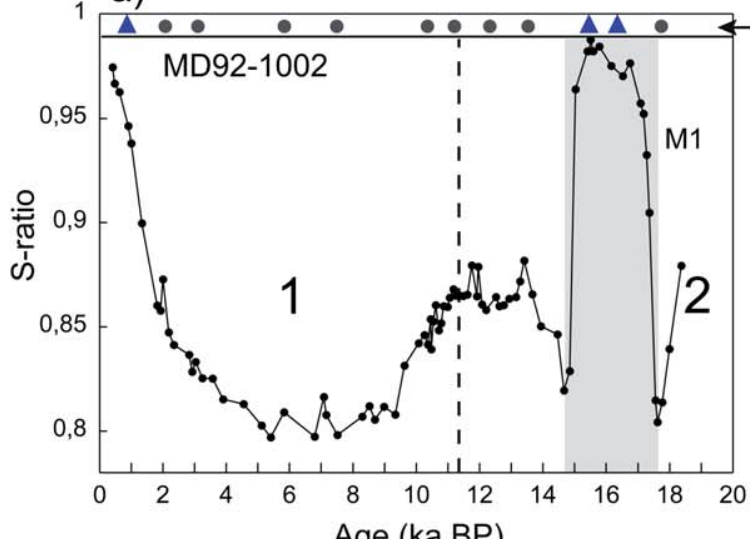

b)

c)

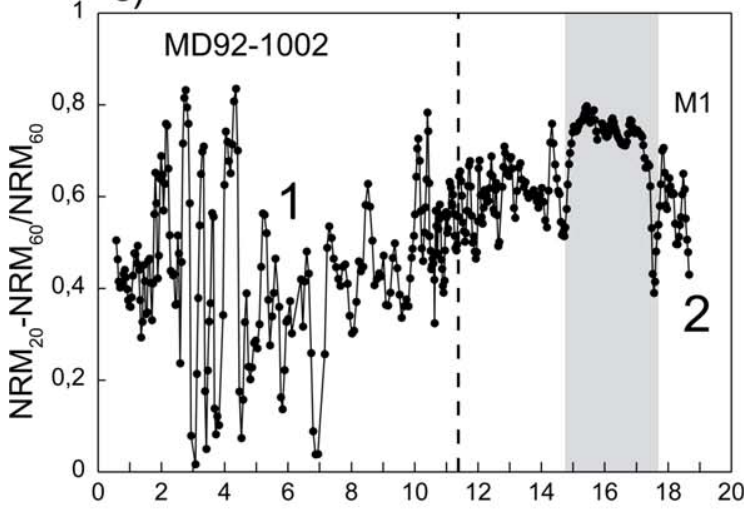

e)

Age (ka BP)
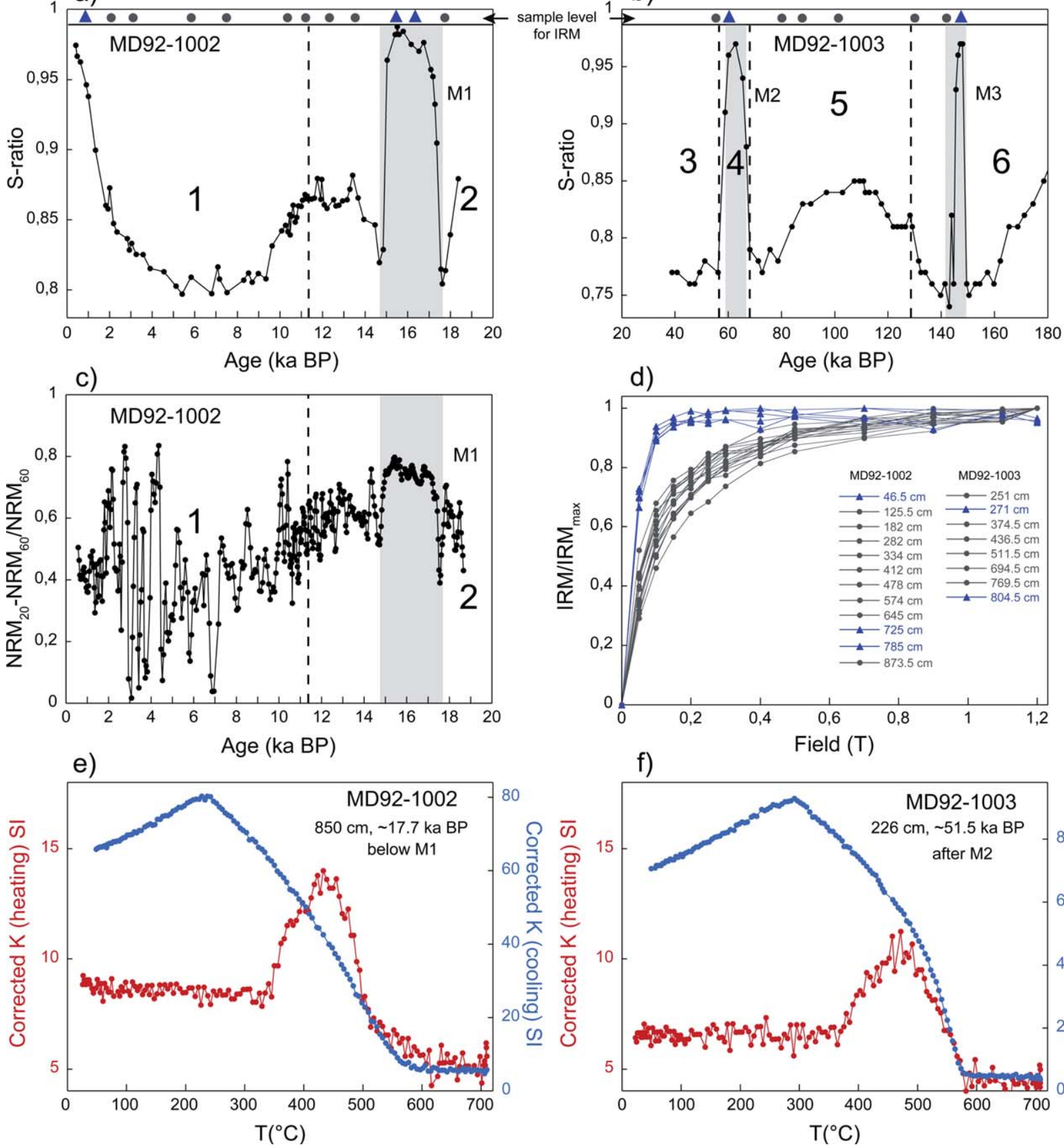

d)

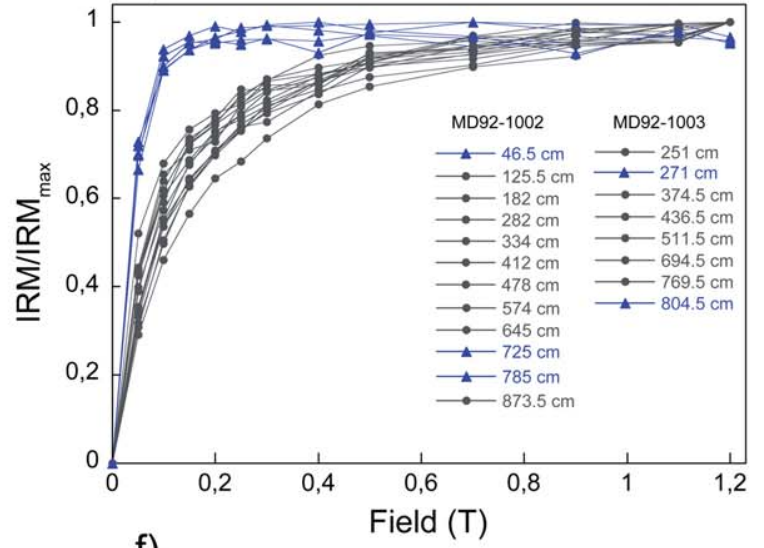

f)

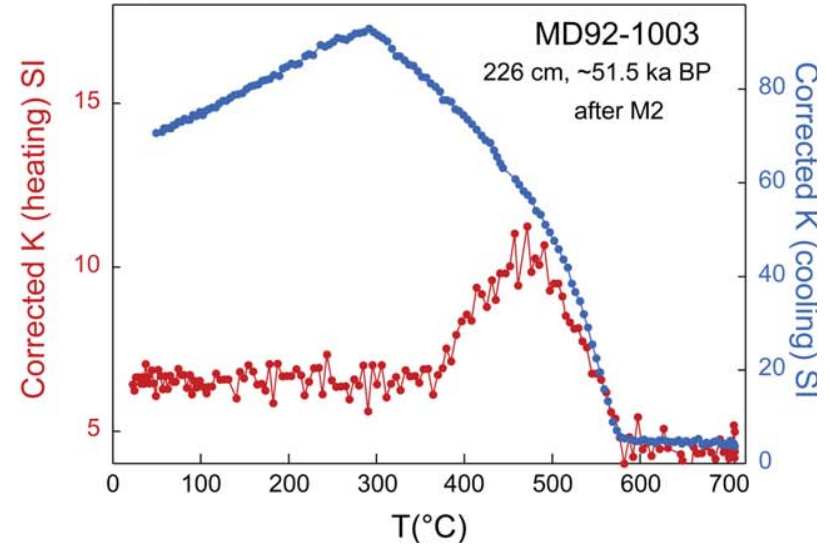

Figure 5. (a and b) $S$ ratio for cores MD92-1002 and MD92-1003. The high values correspond to the M1-M3 episodes. (c) $R$ ratio $\left(\left(\mathrm{NRM}_{20} \mathrm{mT}-\mathrm{NRM}_{60 \mathrm{mT}}\right) / \mathrm{NRM}_{60 \mathrm{mT}}\right)$. (d) IRM acquisition curves for cores MD92-1002 and MD92-1003. Rapid saturation is obtained for samples within the peaks (blue curves). (e and f) Thermomagnetic curves of two samples from cores MD92-1002 and MD92-1003 outside the M1 and M2 susceptibility peaks.

Instead, there is a strong increase during heating within the $350-450^{\circ} \mathrm{C}$ interval, which is most likely caused by the oxidation of pyrite into magnetite [Passier et al., 2001]. Scanning electron microscope (SEM) observations coupled with EDS (energy dispersive X-ray spectroscopy) analyses indicate that the amount of pyrite is lower within the peak than outside. The cooling curves show $K$ increasing below $580^{\circ} \mathrm{C}$ and thus appear to be entirely dominated by magnetite. In a few samples (e.g., in Figure 5e) magnetite is likely associated with a very little amount of titanium. A significant part of magnetite results also from mineralogical alteration during heating. 

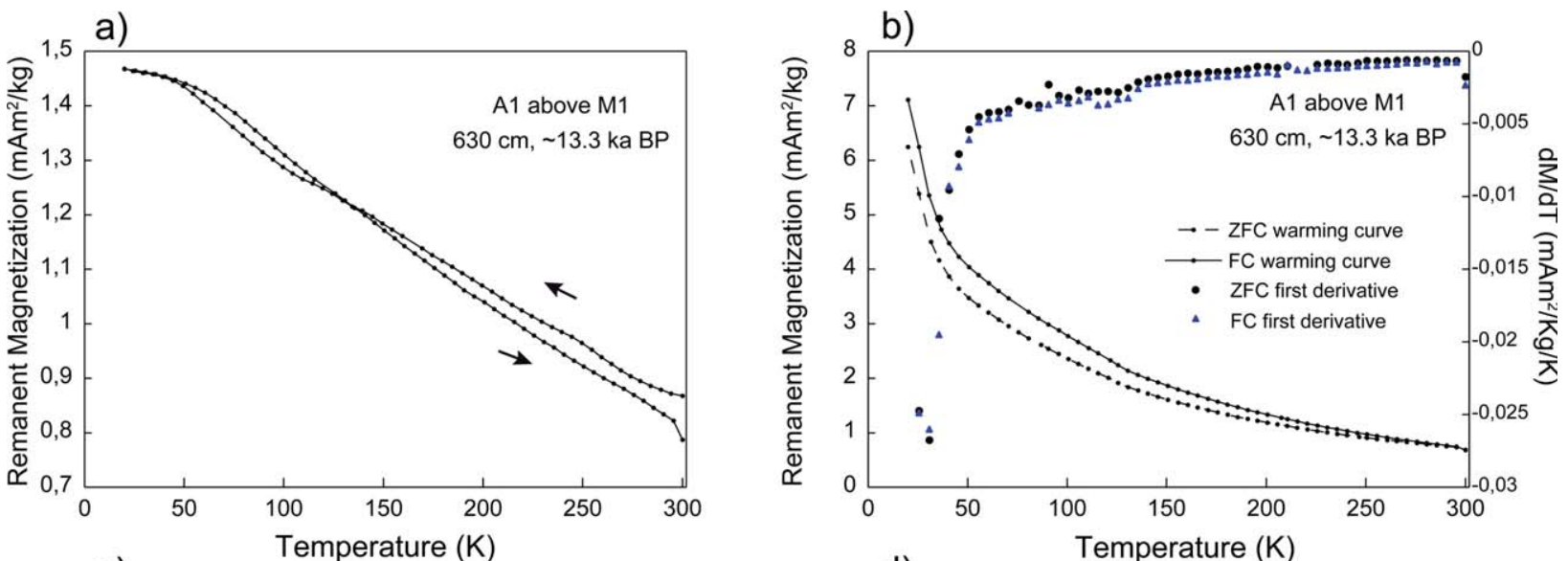

c)
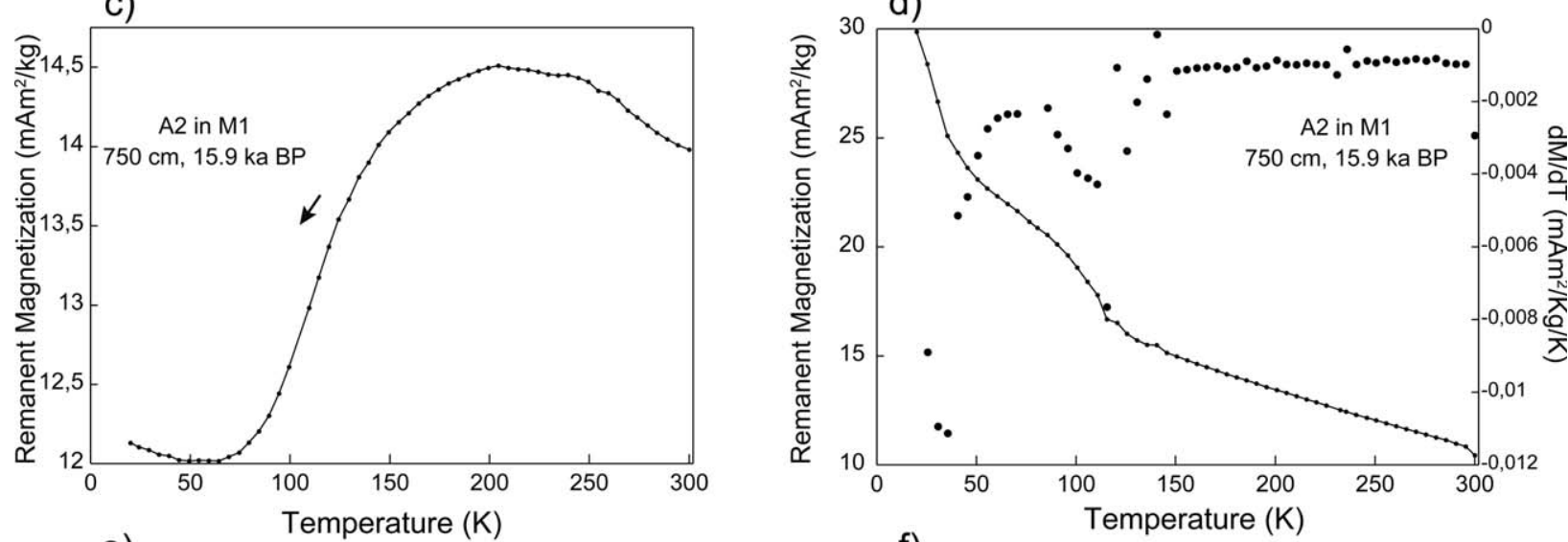

e)
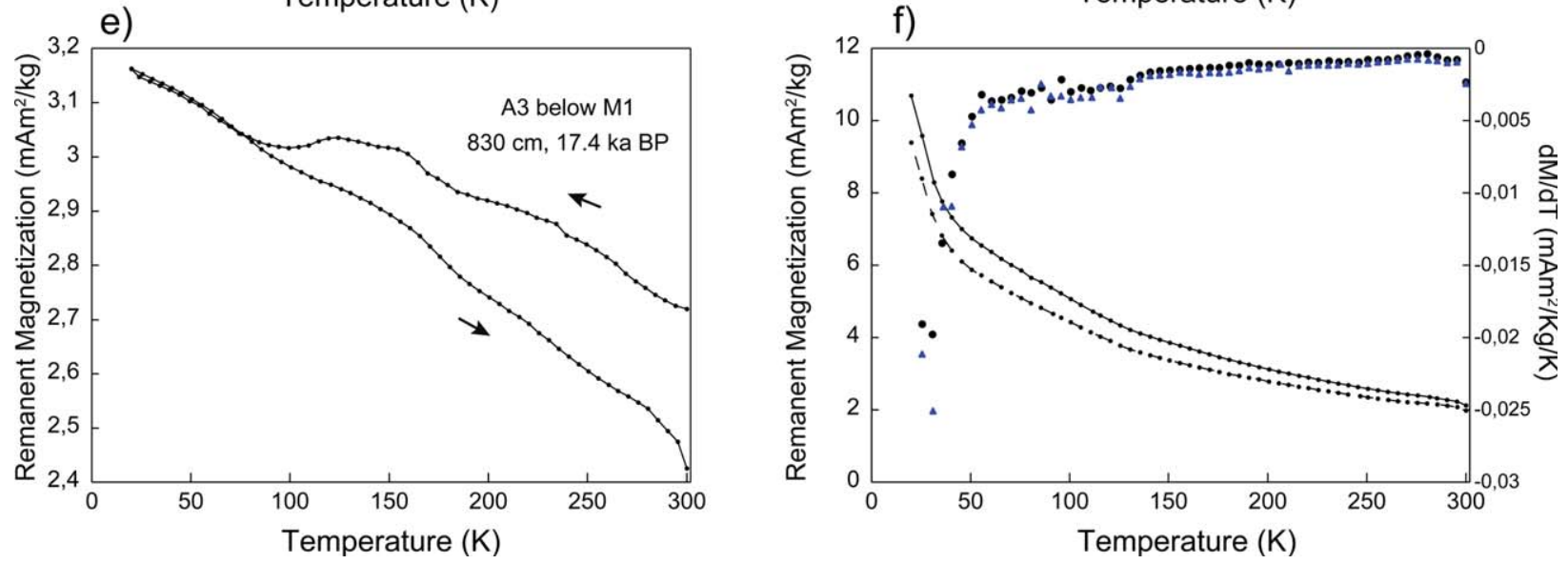

Figure 6. (a, c, and e) RT-SIRM curves of samples from core MD92-1002 measured above M1 (A1), within M1 (A2) and just below M1 (A3). (b, d, and f) ZFC and FC magnetization curves at the same levels. A2 was only subjected to cooling experiments. The first derivatives are shown by filled symbols for ZFC and open symbols for FC. All samples are weight-normalized.

[27] The presence of hematite can be indicated by the $T$ ratio [Meynadier et al., 1992, 1995], which is the remaining percentage of IRM after heating to $600^{\circ} \mathrm{C}$ and calculated as $\left(\mathrm{IRM}-\mathrm{IRM}_{600^{\circ} \mathrm{C}}\right) /$ $\mathrm{IRM}_{600^{\circ} \mathrm{C}}$. We found no significant magnetization beyond $600^{\circ} \mathrm{C}$, which confirms that the highcoercivity mineral is likely not hematite. It could be argued that hematite disappeared due to mineralogical transformations of the sediment while heating up to $600^{\circ} \mathrm{C}$. However, heating was performed in air so that most magnetic materials should have oxidized. Therefore, the zero magnetization above $580-600^{\circ} \mathrm{C}$ confirms the absence of hematite. In summary, the $\mathrm{M}$ peaks appear to be dominated by magnetite, while the other intervals incorporate a high-coercivity mineral. 

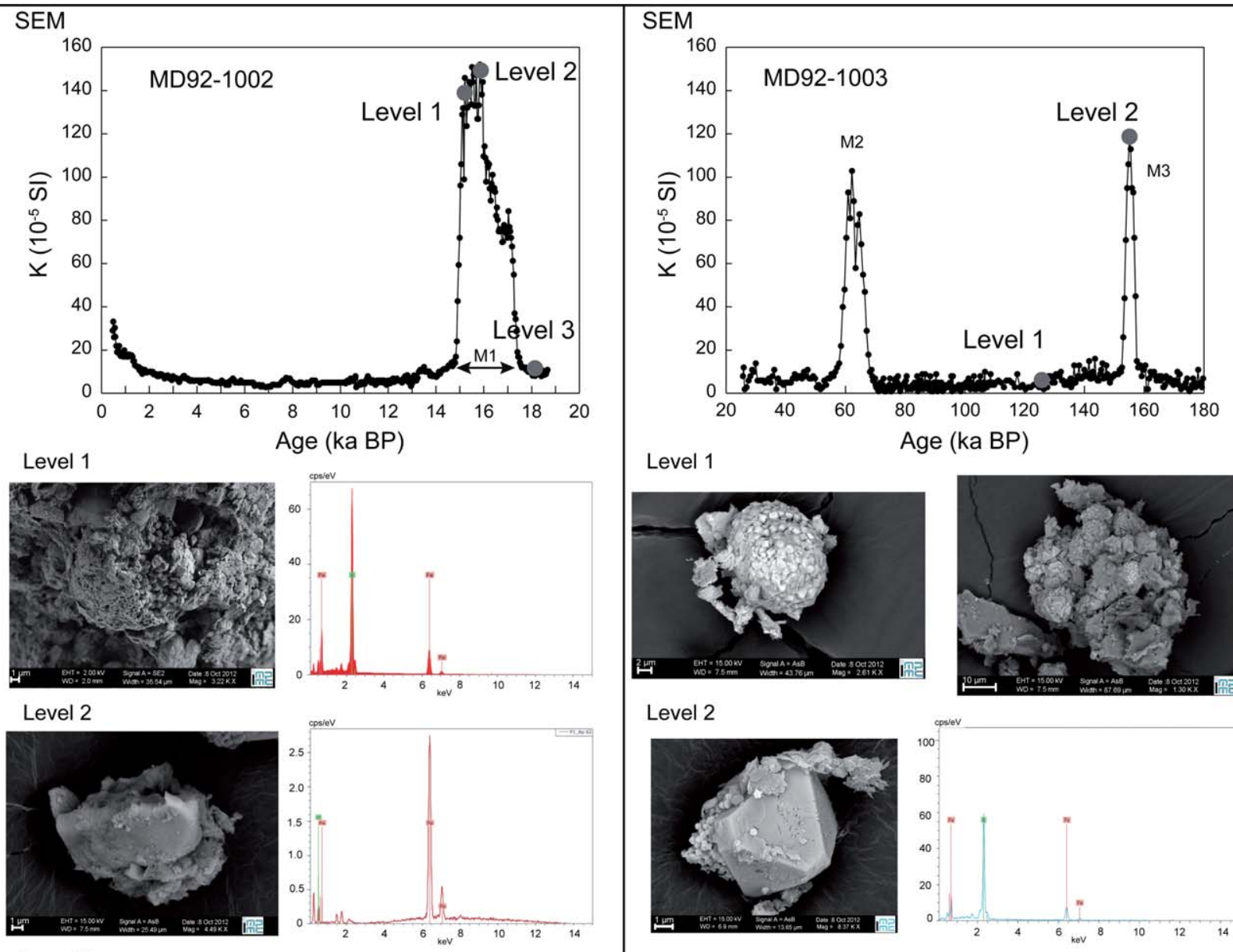

Level 1
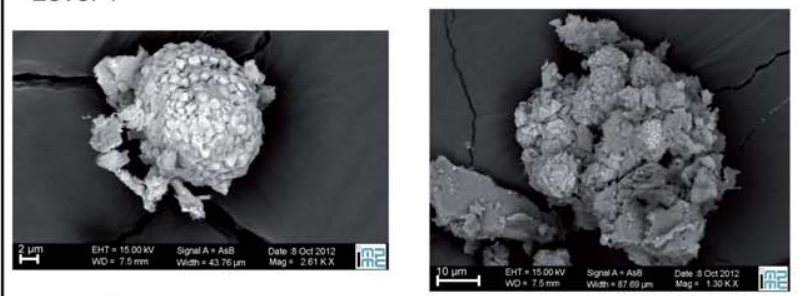

Level 2
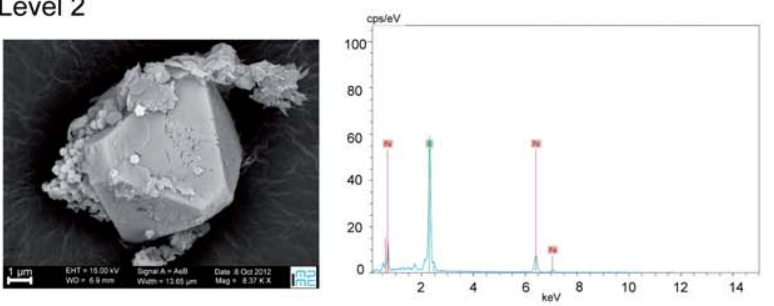

Level 3
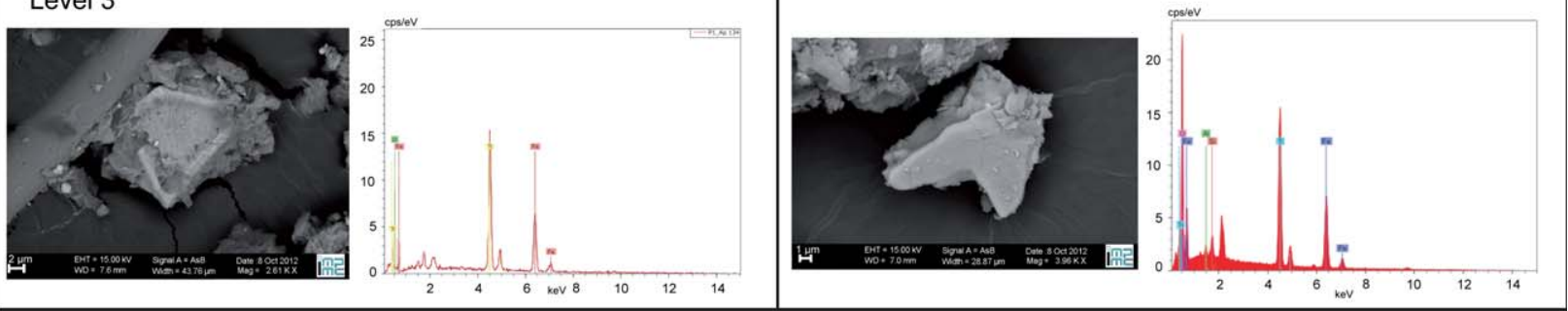

\section{HRTEM}

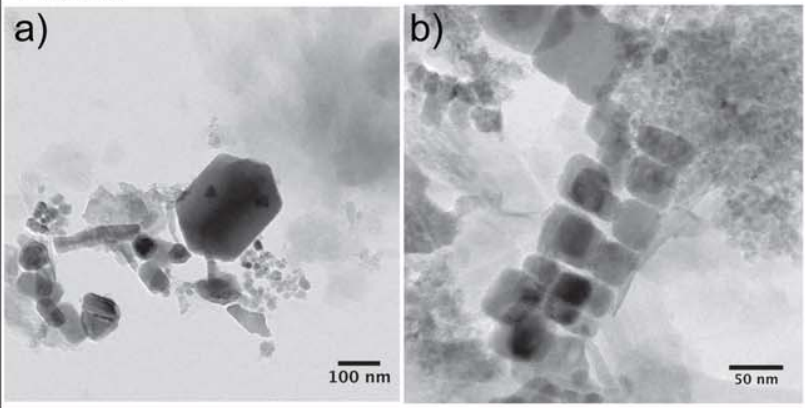

c)

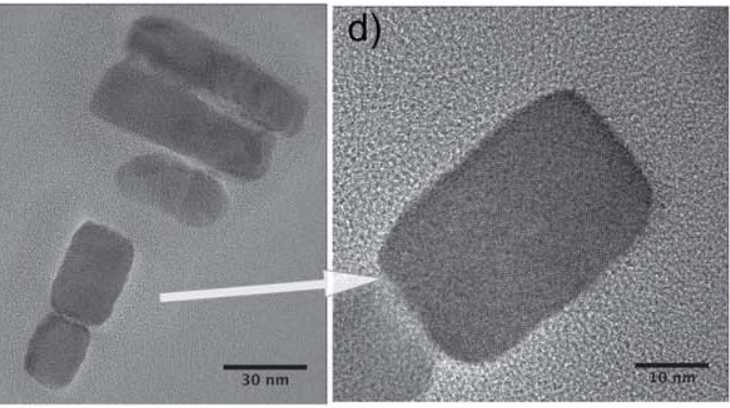

Figure 7. SEM observations of decarbonated sediment powders within and outside the $\mathrm{M}$ peaks from cores MD92-1002 and MD92-1003 and their associated EDS spectra. (left) Level 1 from core MD92-1002 contains framboid of pyrite mycrocrystals, levels 2 and 3 contain iron and iron-titanium oxides. (right) Levels 1 and 2 from core MD92-1003 also contain pyrite and oxides. High-resolution transmission electron microscopy observations of a magnetic extract from core MD92-1003, (a-c) magnetite grains organized in chains, and (d) detailed picture of presumed bacterial magnetite. 
[28] We investigated further the existence of iron sulfides. X-ray diffraction analyses (using a Bruker AXS D2 Phaser with a LynxEye position sensitive detector at the MNHN) on decarbonated, dry powders of four samples from core MD92-1002 and two from core MD92-1003 did not reveal any significant peak characteristic of iron sulfides, and specifically, none of the six peaks inherent to greigite.

[29] Further information about the high-coercivity mineral that is responsible for the low $S$ - and $R$-ratio was obtained from low-temperature rock magnetic experiments. Zero-field cooled (ZFC, cooling from 300 to $20 \mathrm{~K}$ in zero field) and fieldcooled (FC, cooling in field from 300 to $20 \mathrm{~K}$ ) measurements were conducted on six samples of dry bulk sediment from core MD92-1002 using a Quantum Design XL5 EverCool Magnetic Properties Measurement System at IPGP. The cycling experiments were performed at $5 \mathrm{~K}$ temperature increments. Room-temperature SIRM (RT-SIRM) of dry bulk sediments was also measured after applying a $1 \mathrm{~T}$ field. Magnetization versus temperature curves for three samples A1, A2, and A3 located above, within, and below the M1 peak, respectively (Figures 6a-6c), reveal a dramatic loss of magnetization between 20 and $300 \mathrm{~K}$ for samples A1 and A3, whereas there is a noticeable increase for the A2 sample. The low temperature experiments for $\mathrm{A} 1$ and $\mathrm{A} 3$ (Figures $6 \mathrm{~b}$ and $6 \mathrm{f}$ ) are characterized by converging ZFC and $\mathrm{FC}$ heating curves, which are consistent with the presence of goethite [Liu et al., 2006; Franke et al., 2007; Just et al., 2012]. There is also a clear Verwey transition in the heating curve for sample A2 and its derivative (Figure 6d), which is indicative of stoichiometric magnetite. Little evidence for similar transitions is present in the other two samples. Finally, the absence of a Morin transition at $250 \mathrm{~K}$ confirms the absence of hematite. However, we are aware that we cannot be more conclusive about this without saturation experiments in higher fields.

[30] Scanning electron microscope observations coupled with EDS analyses provided another way to characterize magnetic minerals. Twelve decarbonated samples from core MD92-1002 and two samples from core MD92-1003 were dispersed on a double-sided carbon tape on sample holders for SEM observations. SEM observations were performed using a Zeiss Ultra 55 SEM coupled with an EDXS QUANTAX microanalyser (BRUKER) at the Institut de Minéralogie et de Physique des Milieux Condensés (IMPMC), Paris. Iron oxides or iron-titanium oxides $(10-20 \mu \mathrm{m})$ and pyrite microcrystals are observed within the $M$ peaks. The presence of spherical framboids containing uniform pyrite microcrystals outside the $\mathrm{M}$ peaks (Figure 7) is consistent with SIRM heating experiments performed within these intervals, which suggest the transformation of pyrite upon heating [Passier et al., 2001]. Octahedral and cubic forms of isolated pyrite microcrystals were found within the $\mathrm{M}$ peaks (Figure 7).

\section{Relative and Total Amounts of Magnetic Iron Oxides}

[31] The magnetic properties of cores MD92-1002 and MD92-1003 result from changes in the relative abundance of low coercivity (magnetite) and high coercivity (goethite). Goethite is characterized by a low saturation magnetization with respect to magnetite. Thus, the relative concentration of the magnetic particles cannot be directly inferred from bulk, rock magnetic parameters. Changes in the magnetic particles concentration can be estimated by assuming that all magnetic grains have the same magnetic mineralogy. This approach rests upon the conversion of the magnetization carried by the goethite grains into the equivalent magnetization which would be carried by the same amount of magnetite grains. This was achieved by taking into account the relative amount of high- versus low-coercivity material derived from the $S$ ratio and the fact that the magnetization of magnetite is at least 200 times stronger than that of goethite [O'Reilly, 1984]. In order to increase our confidence in these estimates (especially over intervals where magnetic susceptibilities are particularly low resulting in a high signal-to-noise ratio), we averaged the values of three successive data points and used their standard deviation to estimate the range of uncertainty. The relative amount of magnetic oxides (RAMO) derived from these calculations shows a considerably smoother profile than the evolution of NRM, $k$, ARM, and IRM in cores MD92-1002 and MD92-1003. The RAMO (Figure 8a) does not change by more than a factor of 2 in core MD921002 , which is considerably lower than the amplitude of $\sim 20$ observed in the variations of rock magnetic parameters. The same conclusion can be drawn for core MD92-1003 (Figure 8b).

[32] Relatively invariant RAMO profiles for the two cores could fortuitously reflect a nearly constant flux of magnetite and goethite through time, even though these two minerals have a different 

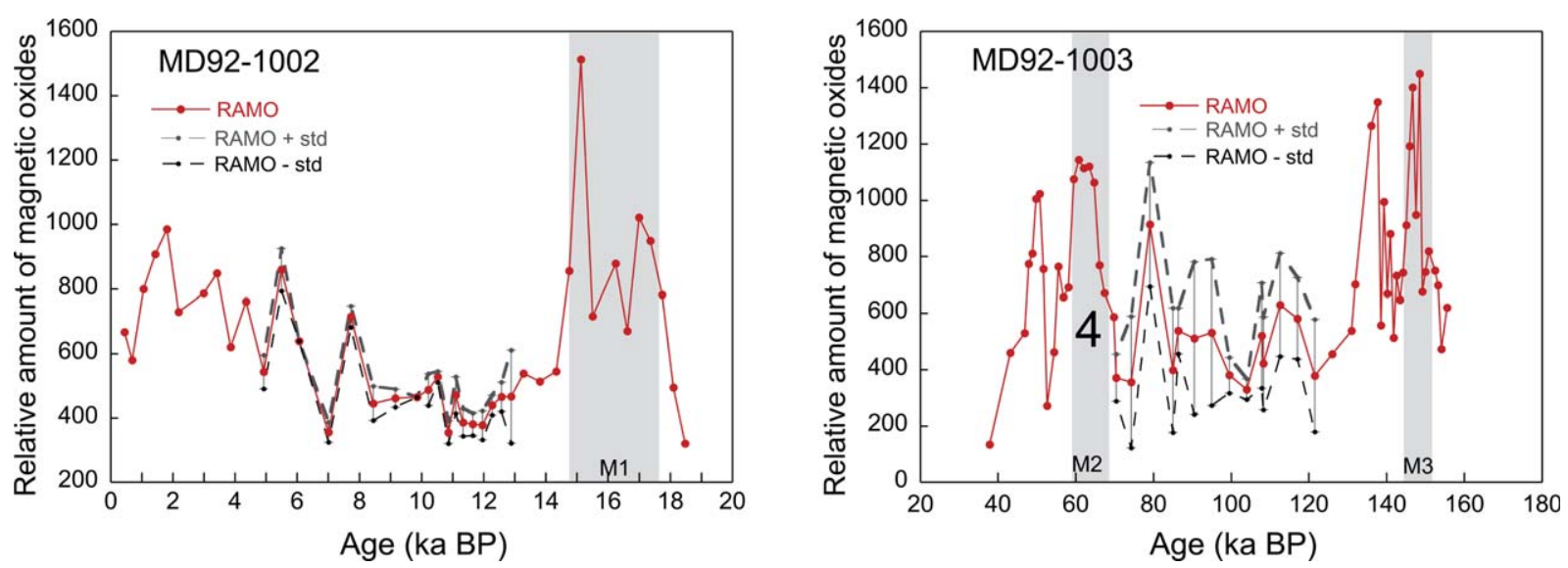

Figure 8. Down-core evolution of the relative amount of magnetic particles (RAMO) in both cores (a) MD92-1002 and (b) MD92-1003 after correcting for the differences in saturation magnetization. Note that the peaks have disappeared.

origin and sedimentation history. In such a scenario, the high-coercivity material (which is dominated by goethite) would have a detrital origin, and its relative abundance would be controlled by source areas and alteration processes (the relative abundance of goethite with respect to hematite reflects more humid conditions). This "fortuitous scenario" appears unlikely. Alternatively, the RAMO profile suggests that the sediment was deposited with a relatively constant concentration of magnetite and that the large changes in magnetic properties ( $k$, NRM, ARM, and IRM) result from postdepositional mineralogical transformations. Redox conditions on the seafloor or during early burial diagenesis would have controlled such mineralogical transformation in this scenario. Reactive iron oxides are dissolved by reduction in anaerobic sediments, which releases $\mathrm{Fe}^{2+}$ near the oxicanoxic boundary. The $\mathrm{Fe}^{2+}$ can be oxidized to $\mathrm{Fe}^{3+}$ at this boundary where authigenic $\mathrm{Fe}^{3+}$-bearing minerals can precipitate. Ferrihydrite has long been considered as a main diagenetic product, but experimental and observational studies indicate that the main reactive precipitate is goethite [van der Zee et al., 2003]. As will be discussed in more detail below, we suggest that the release of $\mathrm{Fe}^{2+}$ and associated precipitation of goethite could be linked to magnetite dissolution.

\section{Organic Carbon}

[33] In order to test whether changes in redox conditions and/or bottom water oxygenation were responsible for changes in magnetite preservation, we measured the total organic carbon (TOC) content remaining in the sediments using an elemental combustion analyzer. Several analyses had been already conducted on 67 decarbonated samples from core MD92-1002 using a LECO C-S 125 analyzer [Ouadhi, 1997]. We analyzed 27 additional nondecarbonated samples from core MD92-1003 with a LECO IR 212 at the Institut des Sciences de la Terre de Paris (Université Pierre et Marie Curie). The $\mathrm{CaCO}_{3}$ content (Cmin for "carbon mineral") was obtained by gas volumetric analysis using a carbonate bomb, and the TOC was estimated by subtracting Cmin from the total carbon (TC) content under the assumption that $\mathrm{Cmin}$ is represented by calcite. TC was determined with a precision of about $0.02 \%$.

[34] Both cores are characterized by relatively large TOC values that range between 0.5 and $\sim 3.5 \%$. In core MD92-1002, TOC progressively increases from $\sim 20 \mathrm{Cal} \mathrm{ka} \mathrm{BP}$ to the present (Figure $9 \mathrm{c})$. An interval characterized by low TOC values $(\sim 0.5 \%)$ occurs at $\sim 14.5-18$ Cal ka BP, while the Younger Dryas has TOC values as low as $\sim 1 \%$. TOC values for core MD92-1003 (Figure 9d) are lower during MIS 4 and 6. The most striking feature is that in both cores the lowest TOC values are coeval with the $\mathrm{M}$ peaks (Figures 9c and 9d). This correlation suggests a dependence between the amount of organic matter and the preservation of magnetite, as frequently observed in magnetic studies of sediments [Froelich et al., 1979; Karlin and Levi, 1983; Karlin, 1990a, 1990b; Leslie et al., 1990; Roberts and Turner, 1993; Richter et al., 1999; Robinson et al., 2000; Liu et al., 2004; Kawamura et al., 2007; Rowan et al., 2009; Abrajevitch et al., 2009; Abrajevitch and Kodama, 2011]. 

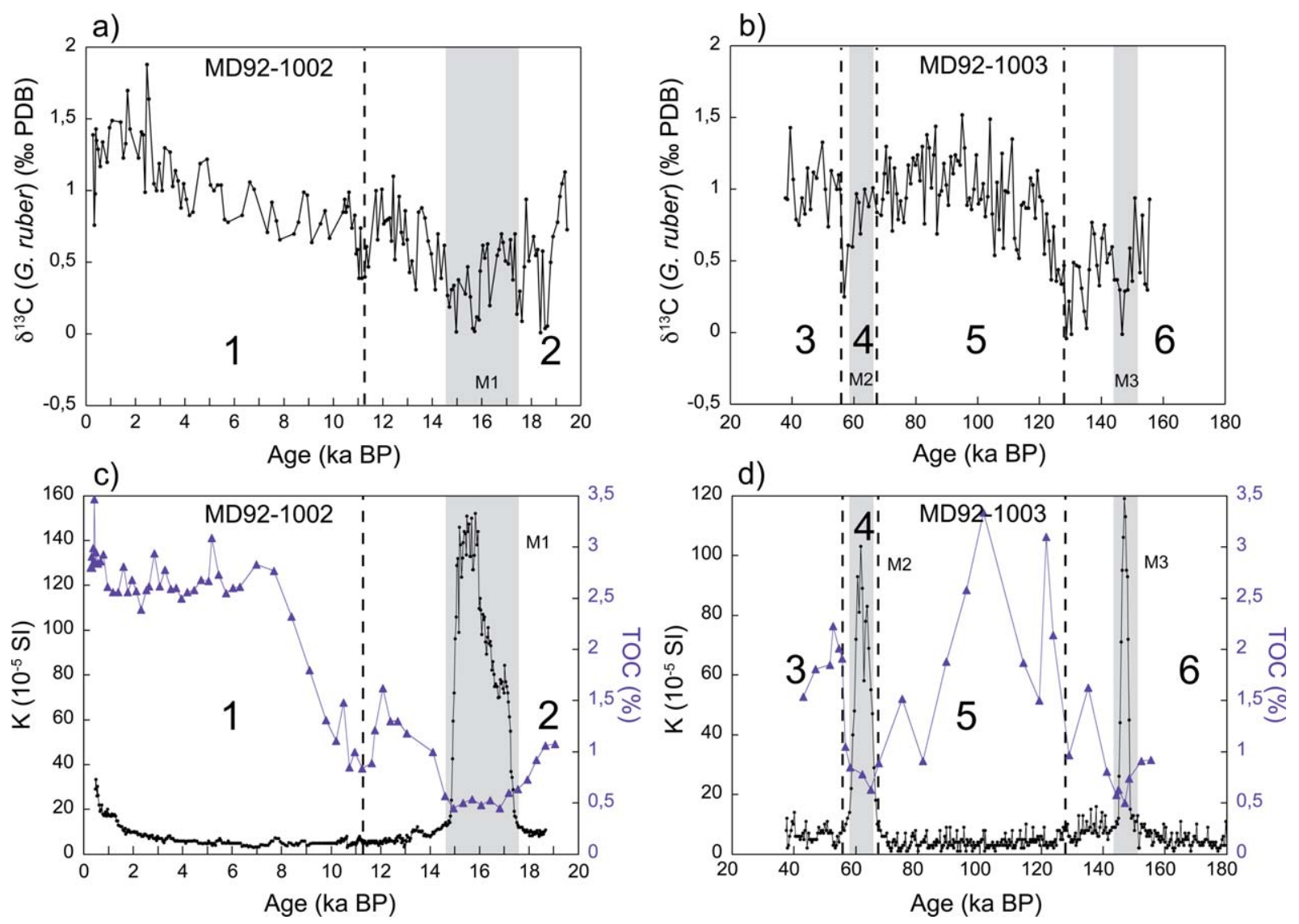

Figure 9. (a and b) $\delta^{13} \mathrm{C}$ profile derived from G. ruber planktonic foraminifera in both cores and (c and d) changes in total organic content (TOC) plotted with susceptibility. The M1-M3 levels have the lowest TOC values.

\section{Discussion}

[35] As seen above, we can exclude hypotheses associated with supply of detrital magnetic minerals for the origin of the high-amplitude susceptibility peaks (M1-M3) found in cores MD92-1002 and MD92-1003. First, the undisturbed oxygen isotopic stratigraphy around the peaks and the detailed ${ }^{14} \mathrm{C}$-based age model for core MD921002 suggest continuous sedimentation. This is confirmed by the absence of sedimentological evidence for turbiditic events or sediment reworking. Density and carbonate content data indicate that neither changes in sediment properties nor carbonate dilution are responsible for the large amplitude changes in magnetic parameters. Major and trace element analyses confirm the existence of a thin volcanic layer in the lower part of M1, which had been previously revealed by smear slide observations of a few disseminated glass shards. However, this volcanic event, which is clearly evident as a small Th peak, does not account for the entire extent (150 cm wide) of M1. In addition, no similar volcanic signature has been found for peaks M2 and M3 in core MD92-1003. $S, R$, and $T$ ratios indicate that magnetic mineralogy is the prominent factor that controls the $M$ peaks. Sediments from core MD92-1002 and MD92-1003 contain magnetite and goethite and magnetite magnetically dominates the $\mathrm{M}$ peaks. With the exception of the small interval containing volcanic glass, geochemical parameters remain largely invariant provided they have been corrected for carbonate dilution. Moreover, under the assumption that magnetite was the only magnetic iron oxide supplied during deposition, we find that the concentration of magnetite has remained almost constant over time. Thus, the nature of sedimentation and the flux of magnetic iron oxides would have remained relatively constant over time.

[36] Our results suggest that significant changes in magnetic mineralogy resulted from early steady state diagenetic transformations, which led to iron oxide dissolution and to subsequent precipitation 
of goethite. The effects of sulfate reducing conditions on preservation of magnetite have been frequently reported [Karlin and Levi, 1983; Canfield and Berner, 1987; Karlin, 1990a, 1990b; Snowball, 1993; Sahota et al., 1995; Passier et al., 2001]. The low likelihood of preservation of detrital magnetite in sulfate reducing environments led us to consider the origin of the single-domain magnetite that dominates the magnetization within the M peaks.

\subsection{Contribution of Magnetosomes}

[37] Despite widespread volcanism in the surrounding area, we cannot neglect the possibility that some of the magnetite from the $\mathrm{M}$ peaks could have a bacterial origin. High-resolution transmission electron microscope (HRTEM) observations of magnetic extracts were performed with a JEOL 2100 TEM at the IMPMC. We selected a magnetite-rich sample taken from the M2 peak in core MD92-1003. Magnetic extraction was conducted on the fine $(<63 \mu \mathrm{m})$ decarbonated fraction following the procedure adapted from Hounslow and Maher [1996]. HRTEM observations of magnetic extracts have revealed the presence of parallelepipeds or bullet-shaped magnetite grains (Figure 7). We also observed a few chains of cubic magnetite crystals (Figures $7 \mathrm{~b}$ and $7 \mathrm{c}$ ) that have the same size as magnetosomes in living magnetotactic bacteria [Kopp and Kirschvink, 2008]. Despite this strong evidence for the presence of fossil magnetosomes, similar aggregates or alignments of magnetite grains could be artificially generated during magnetic extraction.

[38] Biogenic magnetite is often produced within a relatively narrow redox gradient [Bazylinski and Frankel, 2004]. Magnetofossils need sufficient dissolved iron for biomineralization and are almost ubiquitous in aquatic environments. Their preservation depends on the interplay between organic carbon flux (paleoproductivity), iron bioavailability, and redox environment, as shown by Roberts et al. [2011a] who argued that release of iron provided by eolian dust gave rise to paleoproductivity cycles with strong and weak magnetic properties linked to the abundance of magnetofossils. In the present situation, there does not appear to be any direct correlation between the $\mathrm{M}$ peaks and climatic cycles. There is also no evidence for significant changes in the iron content in association with the M peaks.

[39] Alternatively, if deposition rates are rapid the time spent in the active reduction zone is short and favors partial magnetosome preservation. This situation has been reported for sediments from the outer edge of the northeastern Australian continental margin [Abrajevitch and Kodama, 2011]. Two prominent $k$ and SIRM peaks correspond to the onset of marine transgressions with high deposition rates and were interpreted as resulting from a short time period spent within the reduction zone rather than from increased bacterial production. A similar relationship between deposition rates and magnetite preservation was proposed by Snowball [1993] who noticed that higher organic carbon contents combined with low deposition rate produces intense reducing conditions with almost complete loss of magnetite in subarctic lake sediments in northern Sweden. Results from cores MD92-1002 and MD92-1003 are not consistent with these observations because the magnetite peaks do not coincide with faster deposition rates.

[40] Low organic carbon contents with low productivity of magnetotactic bacteria within the $\mathrm{M}$ peaks would also not produce sufficiently strong magnetizations. It seems, therefore, that the relative abundance of pristine single-domain magnetite must be explained by a significant change in redox conditions during deposition of the $\mathrm{M}$ peaks. These results are reminiscent of those of Tarduno [1992] who reported cycles with low and high magnetic mineral concentration in Cretaceous pelagic carbonates from Italy and showed that better preservation of magnetite was coeval with low organic carbon contents. Similar alternances have also been pointed out for the Mediterranean sea sapropels [Larrasoaña et al., 2003].

[41] Changes in diagenetic conditions, due to nonsteady state variation, may be responsible for the different mineralogical contents within and outside the $\mathrm{M}$ peaks. This hypothesis is evidently consistent with the TOC contents outside the $\mathrm{M}$ peaks with values exceeding 4\% in core MD92-1002 and $2.5 \%$ in core MD92-1003. These values are high for hemipelagic sediments. Therefore, we suggest that organic carbon supply was strong enough and/or ventilation of bottom water was weak enough to allow extensive diagenetic sulfate reduction and magnetite dissolution except for within the M peaks.

\subsection{Reductive Dissolution of Magnetite}

[42] The presence of well-preserved single-domain magnetite grains within the $\mathrm{M}$ peaks (with a strong biogenic component), low TOC values, and the absence of iron sulfides indicate that diagenesis did 
not extend beyond the iron reduction stage in these intervals. In contrast, high TOC values, the reduced amount of magnetite, and the presence of framboidal pyrite indicate that diagenetic dissolution of iron oxides has affected the sediment magnetization outside the $\mathrm{M}$ peaks. The occurrence of framboidal pyrite is associated with production of dissolved sulfide by sulfate-reducing bacteria [Canfield and Berner, 1987; Wilkin and Barnes, 1997]. Greigite does not form under highly reducing conditions [Schoonen and Barnes, 1991], but it is still an intermediate product during pyrite in framboid formation [Sweeney and Kaplan, 1973; Morse et al., 1987]. We cannot exclude that greigite rapidly converted into pyrite during early diagenesis [Cutter and Velinsky, 1988], particularly if sulfide production exceeded iron production [Kao et al., 2004]. The fact that the M peaks only contain a few isolated pyrite grains is consistent with this suggestion.

[43] Rock magnetic results from Bengal fan sediments [Abrajevitch et al., 2009] indicate significant changes in relative abundances of goethite, hematite, and magnetite, which can be compared to the present results. In the lower part of the studied Bengal fan sequence, biogenic magnetite and the high-coercivity component carried by goethite and hematite were affected by dissolution. The relative abundance of goethite versus hematite was interpreted as reflecting climate variations in the sediment source area. Other stratigraphic levels are characterized by different degrees of diagenetic dissolution with preferential removal of finegrained (biogenic) fraction of magnetite, relatively high values of TOC, and pyrite occurrences. This alternating pattern of magnetic mineral preservation and destruction resembles that in the present cores except for the balance between magnetite and high-coercivity minerals. In the Bengal fan sediments, goethite and hematite are present within the intervals that were not affected by iron reduction, whereas these minerals are absent within the M peaks in the northern Indian Ocean. Conversely, the goethite content is low when biogenic magnetite is not present in the Bengal sediments, while it is higher where diagenetic reduction took place in our studied Indian Ocean sediments. The absence of goethite within the $\mathrm{M}$ peaks could be the consequence of diagenetic reduction, but in this case the finer grains of magnetite would have been primarily affected.

[44] Goethite reflects different climate or weathering conditions in the source region or in situ diagenetic alteration [Channell et al., 1982; Lowrie and
Heller, 1982; Karlin et al., 1987]. We pointed out that only the second possibility is consistent with a relatively constant supply of magnetite. Several authors [Bloemendal et al., 1992] have observed that during reductive (suboxic) diagenesis [Froelich et al., 1979] there is evidence for the presence of a hard remanence component. Goethite contribution in sediments has previously been underestimated [France and Oldfield, 2000], but it is now frequently observed in detailed rock magnetic studies [Abrajevitch and Kodama, 2011; Just et al., 2012]. It is difficult to determine whether goethite was present during or after diagenesis. In the present situation, the absence or quasi-absence of goethite within the $\mathrm{M}$ peaks strongly suggests that it was inherited from diagenetic depletion of ferrimagnetic constituents. We propose that the $\mathrm{Fe}^{2+}$ released by reductive dissolution of magnetite favored precipitation of this new authigenic phase.

\subsection{Paleoenvironmental Implications}

[45] Early diagenetic dissolution of ferrimagnetic minerals is a potential indicator of paleoenvironmental changes. The high TOC values found in both cores can result from (1) high export productivity from surface to deep waters in the western Arabian Sea where strong monsoon-related upwelling develops during the summer and/or (2) low bottom water oxygenation at intermediate water depths. The two studied sites are now located within a well-developed oxygen minimum zone (OMZ), with bottom water oxygen contents as low as $1 \mathrm{~mL} / \mathrm{L}$ for the deepest site MD92-1002 $(1327 \mathrm{~m})$ and $0.5 \mathrm{~mL} / \mathrm{L}$ for the shallowest site MD92-1003 (485 m) located within the heart of the OMZ (Figure 10). The OMZ is observed across the Arabian Sea and results from oxygen consumption associated with mineralization of exported organic matter at depth, and from moderate rates of thermocline ventilation in the Indian Ocean central water (IOCW) [van Weering et al., 1997]. We suggest that the observed episodes with low TOC in cores MD92-1002 and MD92-1003 and the associated peaks in magnetite preservation result from changes in the extent of oxygen depletion within the OMZ, which generated changes in redox conditions at the seafloor in response to surface productivity changes and/or ventilation of intermediate waters.

[46] Such changes have been documented by several studies, where millennial scale oscillations have been associated with complex atmospheric or oceanic tele-connection mechanisms that transfer high latitude variability to Arabian Sea primary 


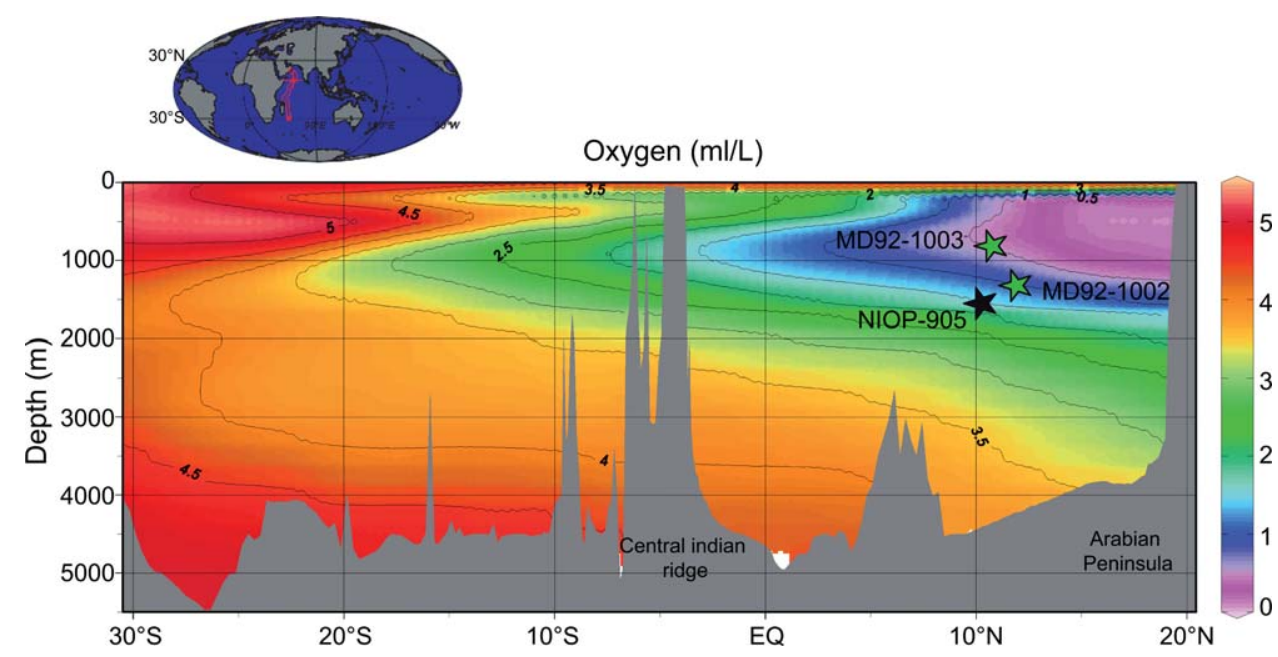

Figure 10. Profile I7 from the Ocean Data view [Schlitzer, 2012] showing oxygen content (mL/L) of Indian Ocean water masses and the paleodepths of cores MD92-1002 and MD92-1003 and NIOP-905.

productivity [Reichart et al., 1998; Schulz et al., 1998; von Rad et al., 1999; Leuschner and Sirocko, 2000; Altabet et al., 2002; Jung et al., 2002] or ventilation of intermediate water through episodic northward extension of the Glacial Antarctic Intermediate Water (GAAIW) into the Arabian Sea [Jung et al., 2009]. In core MD92-1002, the G. ruber $\delta^{13} \mathrm{C}$ curve (G. ruber, shallow signal) is superimposed on the long-term glacial-interglacial pattern. The M1 event ( 15-17 Cal ka BP) corresponds to a $\delta^{13} \mathrm{C}$ minimum (circa $0.25 \%$ )
(Figure 11b), which can be interpreted as reflecting a low productivity episode. In core MD92-1003, the lowest TOC values are coeval with low $\delta^{13} \mathrm{C}$ values. We can infer that these data support the hypothesis that past productivity decreases may have played a key role in generating the $M$ peaks in cores MD92-1002 and MD92-1003. However, other evidence points to the potential role played by ventilation changes at intermediate depths. The epibenthic (Cibicides kullenbergi) $\delta^{13} \mathrm{C}$ record from nearby core NIOP-905, located at a water

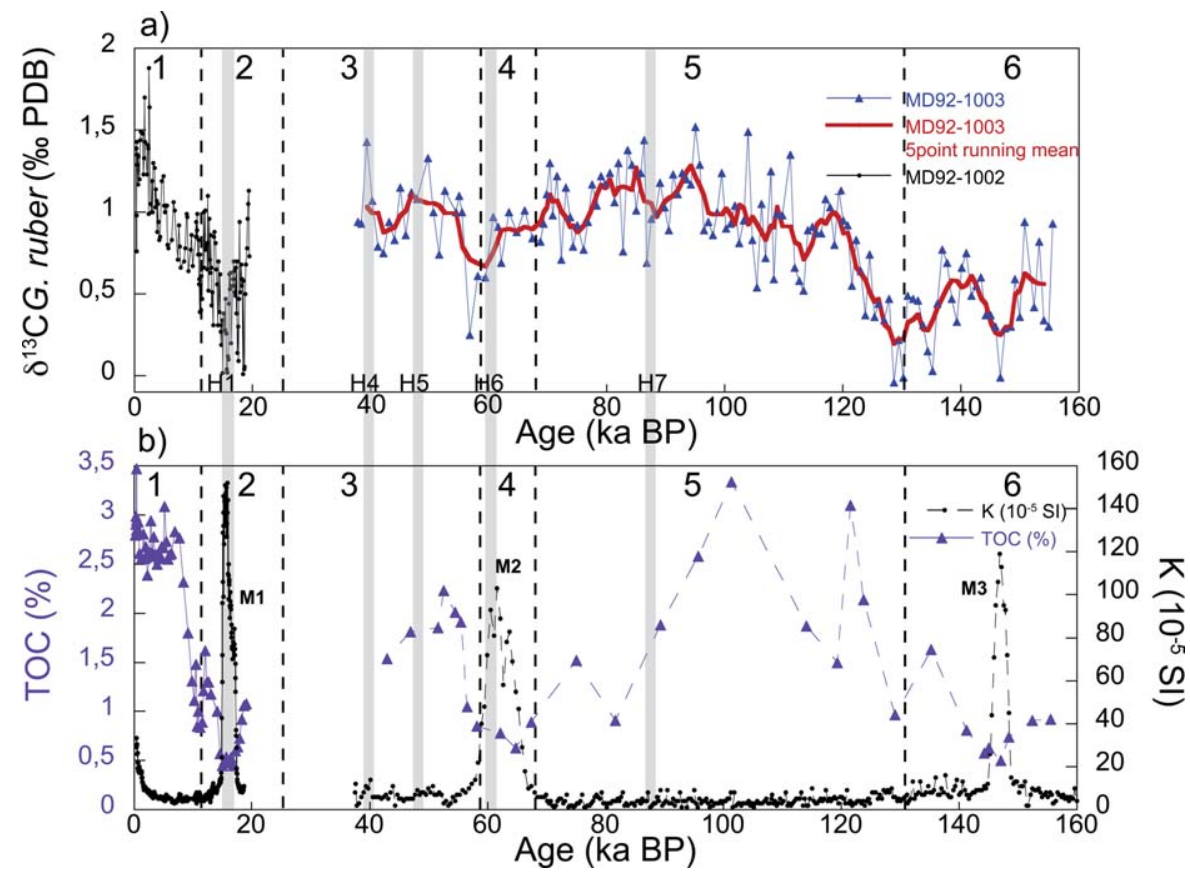

Figure 11. (a) Composite $\delta^{13} \mathrm{C}$ record for G. ruber (shallow water mass) and (b) TOC versus magnetic susceptibility for both cores. 
depth of $1580 \mathrm{~m}$ (about $300 \mathrm{~m}$ deeper than core MD92-1002), reveals several high-amplitude, positive peaks that are not all coeval with sea surface productivity changes and which have been interpreted as reflecting episodic northward GAAIW extensions, in response to reduced thermohaline overturning in the North Atlantic during Heinrichice surge events [Jung et al., 2009].

[47] Within the limits of our well-constrained ${ }^{14} \mathrm{C}$ age model, the M1 peak of core MD92-1002 appears to be synchronous with the youngest high $\delta^{13} \mathrm{C}$ peak in core NIOP-905, which is interpreted as a ventilation event associated with a teleconnected response to Heinrich event 1 [Jung et al., 2009]. Similarly, the M2 peak in core MD921003 can be associated with the Heinrich event 6 (Figure 11). A recent study by Roberts et al. [2011b] from the nearby Red Sea provides evidence for similar tele-connections and responses to Heinrich events. However, the orbitally tuned age model of core MD92-1003 is not precise enough to unambiguously support this assumption. It is puzzling that the benthic $\delta^{13} \mathrm{C}$ record of NIOP-905 has many more peaks than the magnetic susceptibility record for core MD92-1003 which does not reveal any peak corresponding to the H3, H4, and H5 events. Because core MD92-1003 (at $\sim 485 \mathrm{~m}$ water depth) is located in the heart of the modern OMZ, while the deeper NIOP-905 site $(1580 \mathrm{~m})$ is located at its lowermost limit, we speculate that core NIOP-905 could be more sensitive to changes in intermediate ventilation associated with northward extension of the GAAIW. Additional studies of benthic $\delta^{13} \mathrm{C}$ and surface productivity proxies are required to assess the respective role of productivity and ventilation on TOC changes and sedimentary redox variations in the Northern Indian Ocean.

\section{Conclusions}

[48] We investigated down-core changes in magnetic mineral concentration, mineralogy, and grain size in two sediment cores from the Gulf of Aden and a parallel multiproxy sedimentological (carbonate content, bulk density, TOC) and geochemical (major and trace elements, high resolution of $\delta^{18} \mathrm{O}$ and $\left.\delta^{13} \mathrm{C}\right)$ study. TOC contents combined with the presence of framboidal pyrite and major changes in magnetic mineralogy indicate that part of an initial magnetite contribution likely associated with magnetotactic bacteria was diagenetically reduced. The presence of goethite at the same levels resulted from diagenetic release of $\mathrm{Fe}^{2+}$ which precipitated as authigenic iron oxyhydroxides. This study was initially aimed at investigating the origin of high-amplitude susceptibility peaks in both cores, which are shown to have been induced by a switch from a magnetitegoethite assemblage to a purely magnetitedominated regime. Such changes occurred either during low productivity episodes and/or episodes of OMZ breakdown, which resulted from northward extension of the well-oxygenated GAAIW.

[49] Our results suggest several conclusions. First, they emphasize the importance of paying attention to magnetic mineralogy in marine sediments, even in the presence of small changes between contributions from high- and low-coercivity magnetic minerals. Variations between low- and highcoercivity minerals rapidly generate large changes in magnetization properties, but they do not necessarily affect the fidelity of the paleomagnetic record. We reiterate the warning of Abrajevitch et al. [2009] regarding the use of magnetic parameters as paleoenvironmental indicators in the presence of diagenetic alteration. This diagenetic imprint may affect the interpretation of magnetic analyses (e.g., grain size and magnetic anisotropy) and other parameters that are frequently used in environmental magnetism. Second, our work demonstrates the value of magnetic, mineralogical, and geochemical parameters in investigating paleoenvironmental conditions during sediment deposition. Finally, we emphasize the potential role played by magnetotactic bacteria, which has been pointed out in an increasing number of recent studies [e.g., Roberts et al., 2012].

\section{Acknowledgments}

[50] The authors are pleased to acknowledge A.M Brunet (MNHN) for carbonate analyses, I. Esteve and J.Li (UPMC) for SEM and HRTEM observations and F. Baudin (UPMC) for his help concerning the TOC measurements. Andy Roberts generously improved the manuscript and provided helpful comments with another anonymous reviewer. This work was supported by the MAG-ORB program (ANR-09-BLAN-005301) from the French Agence Nationale de la Recherche. This is IPGP contribution 3412 and LSCE contribution 5033.

\section{References}

Abrajevitch, A., and K. Kodama (2011), Diagenetic sensitivity of paleoenvironmental proxies: A rock magnetic study of Australian continental margin sediments, Geochem. Geophys. Geosyst., 12, Q05Z24, doi:10.1029/2010GC003481. 
Abrajevitch, A., R. Van der Voo, and D. K. Rea (2009), Variations in relative abundances of goethite and hematite in Bengal Fan sediments: Climatic vs. diagenetic signals, Mar. Geol., 267, 191-206, doi:10.1016/j.margeo.2009.10.010.

Altabet, M. A., M. J. Higginson, and D. W. Murray (2002), The effect of millennial-scale changes in Arabian Sea denitrification on atmospheric $\mathrm{CO}_{2}$, Nature, 415, 159-162, doi: $10.1038 / 415159$ a.

Bassinot, F. C., L. D. Labeyrie, E. Vincent, X. Quidelleur, N. J. Shackleton, and Y. Lancelot (1994), The astronomical theory of climate and the age of the Brunhes-Matuyama magnetic reversal, Earth Planet. Sci. Lett., 126, 91-108, doi:10.1016/0012-821X(94)90244-5.

Bazylinski, D. A., and R. B. Frankel (2004), Magnetosome formation in prokaryotes, Nat. Rev. Microbiol., 2, 217-230, doi:10.1038/nrmicro842.

Bloemendal, J., N. Lamb, and J. King (1988), Paleoenvironmental implications of rock-magnetic properties of late quaternary sediment cores from the Eastern Equatorial Atlantic, Paleoceanography, 3, 61-87, doi:10.1029/ PA003i001p00061.

Bloemendal, J., J. W. King, F. R. Hall, and S-J. Doh (1992), Rock magnetism of Late Neogene and Pleistocene deep-sea sediments: Relationship to sediment source, diagenetic processes and sediment lithology, J. Geophys. Res., 97, 4361-4375, doi:10.1029/91JB03068.

Canfield, D. E., and R. A. Berner (1987), Dissolution and pyritization of magnetite in anoxic marine sediments, Geochim. Cosmochim. Acta, 51, 645-659, doi:10.1016/ 0016-7037(87)90076-7.

Channell, J. E. T., R. Freeman, F. Heller, and W. Lowrie (1982), Timing of diagenetic haematite growth in red pelagic limestones from Gubbio (Italy), Earth Planet. Sci. Lett., 58, 189-201, doi:10.1016/0012-821X(82)90193-5.

Cogné, J. P. (2003), PaleoMac: A Macintosh ${ }^{\mathrm{TM}}$ application for treating paleomagnetic data and making plate reconstructions, Geochem. Geophys. Geosyst., 4(1), 1007, doi:10.1029/ $2001 \mathrm{GC} 000227$.

Cutter, G. A., and D. J. Velinsky (1988), Temporal variations of sedimentary sulphur in a Delaware salt marsh, Mar. Chem., 23, 311-327, doi:10.1016/0304-4203(88)90101-6.

deMenocal, P., J. Bloemendal, and J. King (1991), A rockmagnetic record of monsoonal dust deposition to the Arabian sea: Evidence for a shift in the mode of deposition at $2.4 \mathrm{Ma}$, Proc. Ocean Drilling Program Sci. Results, 117, 389-407.

Emiliani, C. (1955), Pleistocene temperatures, J. Geol., 63, 538-578.

France, D. E., and F. Oldfield (2000), Identifying goethite and hematite from rock magnetic measurements of soils and sediments, J. Geophys. Res., 105, 2781-2795, doi:10.1029/ 1999JB900304.

Franke, C., T. Frederichs, and M. J. Dekkers (2007), Efficiency of heavy liquid separation to concentration magnetic particles, Geophys. J. Int., 170, 1053-1066, doi:10.1111/ j.1365-246X.2007.03489.x.

Froelich, P. N., G. P. Klinkhammer, M. L. Bender, G. R. Luedtke, G. R. Heath, D. Cullen, P. Dauphin, D. Hammond, B. Hartman, and V. Maynard (1979), Early oxidation of organic matter in pelagic sediments of the eastern equatorial Atlantic: Suboxic diagenesis, Geochim. Cosmochim. Acta, 43, 1075-1090, doi:10.1016/0016-7037(79)90095-4.

Haag, M. (2000), Reliability of relative paleointensities of a sediment core with climatically-triggered strong magnetisa- tion changes, Earth Planet. Sci. Lett., 180, 49-59, doi:10.1016/S0012-821X(00)00145-X.

Hounslow, M. W., and B. A. Maher (1996), Quantitative extraction and analysis of carriers of magnetization in sediments, Geophys. J. Int., 124, 57-74, doi:10.1111/ j.1365-246X.1996.tb06352.x.

Joron, J. L., M. Treuil, and L. Raimbault (1997), Activation analysis as a geochemical tool: Statement of its capabilities for geochemical trace element studies, J. Radioanal. Nucl. Chem., 216, 229-235, doi:10.1007/BF02033783.

Jung, S. J. A., G. R. Davies, G. Ganssen, and D. Kroon (2002), Decadal-centennial scale monsoon variations in the Arabian Sea during the early Holocene, Geochem. Geophys. Geosyst., 3(10), 1060, doi:10.1029/2002GC000348.

Jung, S. J. A., D. Kroon, G. Ganssen, F. Peeters, and R. Ganeshram (2009), Enhanced Arabian Sea intermediate water flow during glacial North Atlantic cold phases, Earth Planet. Sci. Lett., 280, 220-228, doi:10.1016/j.epsl.2009.01.037.

Just, J., M. J. Dekkers, T. von Dobenek, A. van Hoesel, and T. Bickert (2012), Signatures and significance of eolian, fluvial, bacterial and diagenetic magnetic mineral fractions in late quaternary marine sediments off Gambia, NW Africa, Geochem. Geophys. Geosyst., 13, Q0AO02, doi:10.1029/ 2012GC004146.

Kao, S. J., C. S. Horng, A. P. Roberts, and K. K. Liu (2004), Carbon-sulfur-iron relationships in sedimentary rocks from southwestern Taiwan: Influence of geochemical environment on greigite and pyrrhotite formation, Chem. Geol., 203, 153-168, doi:10.1016/j.chemgeo.2003.09.007.

Karlin, R. (1990a), Magnetite diagenesis in marine sediments from the Oregon continental margin, J. Geophys. Res., 95, 4405-4419, doi:10.1029/JB095iB04p04405.

Karlin, R. (1990b), Magnetic mineral diagenesis in suboxic sediments at Bettis site W-N, NE Pacific Ocean, J. Geophys. Res., 95, 4421-4436, doi:10.1029/JB095iB04p04421.

Karlin, R., and S. Levi (1983), Diagenesis of magnetic minerals in recent haemipelagic sediments, Nature, 303, 327-330, doi: 10.1038/303327a0.

Karlin, R., M. Lyle, and G. R. Heath (1987), Authigenic magnetite formation in suboxic marine sediments, Nature, 326, 490-493, doi:10.1038/326490a0.

Kawamura, N., H. Oda, K. Ikehara, T. Yamazaki, K. Shioi, S. Taga, S. Hatakeyama, and M. Torii (2007), Diagenetic effect on magnetic properties of marine core sediments from the southern Okhotsk Sea, Earth Planets Space, 59, 83-93.

Kopp, R. E., and J. L. Kirschvink (2008), The identification and biogeochemical interpretation of fossil magnetotactic bacteria, Earth Sci. Rev., 86, 42-61, doi:10.1016/ j.earscirev.2007.08.001.

Larrasoaña, J. C., A. P. Roberts, J. S. Stoner, C. Richter, and R. Wehausen (2003), A new proxy for bottom-water ventilation in the eastern Mediterranean based on diagenetically controlled magnetic properties of sapropel-bearing sediments, Palaeogeogr. Palaeoclimatol. Palaeoecol., 190, 221-242, doi:10.1016/S0031-0182(02)00607-7.

Larrasoaña, J. C., A. P. Roberts, A. Hayes, R. Wehausen, and E. J. Rohling (2006), Detecting missing beats in the Mediterranean climate rhythm from magnetic identification of oxidized sapropels (Ocean Drilling Program Leg 160), Phys. Earth Planet. Inter., 156, 283-293, doi:10.1016/ j.pepi.2005.04.017.

Lean, C. M. B., and I. N. McCave (1998), Glacial to interglacial mineral magnetic and paleoceanographic changes at Chatham Rise, SW Pacific Ocean, Earth Planet. Sci. Lett., 163, 247-260, doi:10.1016/S0012-821X(98)00191-5. 
Leslie, B. W., D. E. Hammond, W. M. Berelson, and S. P. Lund (1990), Diagenesis in anoxic sediments from the California Continental Borderland and its influence on iron, sulfur, and magnetite behaviour, J. Geophys. Res., 95, 44534470, doi:10.1029/JB095iB04p04453.

Leuschner, D. C., and F. Sirocko (2000), The low-latitude monsoon climate Dansgaard-Oeschger cycles and Heinrich Events, Quat. Sci. Rev., 19, 243-254, doi:10.1016/S02773791(99)00064-5.

Liu, J., R. Zhu, A. P. Roberts, S. Li, and J.-H. Chang (2004), High-resolution analysis of early diagenetic effects on magnetic minerals in post-middle-Holocene continental shelf sediments from the Korea Strait, J. Geophys. Res., 109, B03103, doi: 10.1029/2003JB002813.

Liu, Q., Y. Yu, J. Torrent, A. P. Roberts, Y. Pan, and R. Zhu (2006), Characteristic low-temperature magnetic properties of aluminous goethite $[\alpha-(\mathrm{Fe}, \mathrm{Al}) \mathrm{OOH}]$ explained, $J$. Geophys. Res., 111, B12S35, doi:10.1029/2006JB004560.

Lowrie, W., and F. Heller (1982), Magnetic properties of marine limestones, Rev. Geophys. Space Phys., 20, 171-192, doi:10.1029/RG020i002p00171.

Meynadier, L., J-P. Valet, R. Weeks, N. J. Shackleton, and V. Lee Hagee (1992), Relative geomagnetic intensity of the field during the last $140 \mathrm{ka}$, Earth Planet. Sci. Lett., 114, 39-57, doi:10.1016/0012-821X(92)90150-T.

Meynadier, L., J-P. Valet, and F. E. Grousset (1995), Magnetic properties and origin of upper Quaternary sediments in the Somali Basin, Indian Ocean, Paleoceanography, 10, 459472, doi:10.1029/94PA03151.

Morse, J. W., F. J. Millero, J. C. Comwell, and D. Rickard (1987), The chemistry of the hydrogen sulfide and iron sulfide systems in natural waters, Earth Sci. Rev., 24, 1-42, doi:10.1016/0012-8252(87)90046-8.

Nagy, E. A., and J. Valet (1993), New advances for paleomagnetic studies of sediment cores using U-Channels, Geophys. Res. Lett., 20, 671-674, doi:10.1029/93GL00213.

O'Reilly, W. (1984), Rock and Mineral Magnetism, 230 pp., Blackie, Glasgow, U. K.

Ouadhi, R. (1997), Paléocéanographie et paléoproductivité liées à la mousson Indienne dans le bassin de Somalie, le Golfe d'Aden et la Mer Rouge durant les derniers 460000 ans, Thèse de Doctorat, 166 pp., Mus. Natl. d'Hist. Nat., Paris.

Paillard, D., L. Labeyrie, and P. Yiou (1996), Macintosh program performs time-series analysis, Eos Trans. $A G U$, 77(39), 379-379, doi:10.1029/96EO00259.

Passier, H. F., G. J. de Lange, and M. J. Dekkers (2001), Magnetic properties and geochemistry of the active oxidation front at the youngest sapropel in the eastern Mediterranean Sea, Geophys. J. Int., 145, 604-614, doi:10.1046/j.0956540x.2001.01394.x.

Reichart, G. J., L. J. Lourens, and W. J. Zachariasse (1998), Temporal variability in the Northern Arabian Sea oxygen minimum zone (OMZ) during the last 225,000 years, Paleoceanography, 13, 607-621, doi:10.1029/98PA02203.

Reimer, P. J., et al. (2009), IntCal09 and Marine09 radiocarbon age calibration curves, $0-50,000$ years cal BP, Radiocarbon, 51, 1111-1150.

Richter, C., A. Hayashida, Y. Guyodo, and K. L. Verosub (1999), Magnetic intensity loss and core diagenesis in longcore samples from the East Cortez Basin and the San Nicholas Basin (California Borderland), Earth Planets Space, 51, 329-336.
Roberts, A. P. (1995), Magnetic properties of sedimentary greigite $\left(\mathrm{Fe}_{3} \mathrm{~S}_{4}\right)$, Earth Planet. Sci. Lett., 134, 227-236, doi:10.1016/0012-821X(95)00131-U.

Roberts, A. P., and G. M. Turner (1993), Diagenetic formation of ferrimagnetic iron sulphide minerals in rapidly deposited marine sediments, South Island, New Zealand, Earth Planet. Sci. Lett., 115, 257-273, doi:10.1016/0012-821X(93)90226-Y.

Roberts, A. P., F. Florindo, G. Villa, L. Chang, L. Jovane, S. M. Bohaty, J. C. Larrasoaña, D. Heslop, and J. D. Fitz Gerald (2011a), Magnetotactic bacterial abundance in pelagic marine environments is limited by organic carbon flux and availability of dissolved iron, Earth Planet. Sci. Lett., 310, 441-452, doi:10.1016/j.eps1.2011.08.011.

Roberts, A. P., E. J. Rohling, K. M. Grant, J. C. Larrasoaña, and Q. Liu (2011b), Atmospheric dust variability from Arabia and China over the last 500,000 years, Quat. Sci. Rev., 30, 3537-3541, doi:10.1016/j.quascirev.2011.09.007.

Roberts, A. P., L. Chang, D. Heslop, F. Florindo, and J. C. Larrasoaña (2012), Searching for single domain magnetite in the "pseudo-single-domain" sedimentary haystack: Implications of biogenic magnetite preservation for sediment magnetism and relative paleointensity determinations, J. Geophys. Res., 117, B08104, doi:10.1029/2012JB009412.

Robinson, S. G. (1986), The Late Pleistocene paleoclimatic record of the North Atlantic deep-sea sediments revealed by mineral-magnetic measurements, Phys. Earth Planet. Inter., 42, 22-47, doi:10.1016/S0031-9201(86)80006-1.

Robinson, S. G., J. T. S. Sahota, and F. Oldfield (2000), Early diagenesis in North Atlantic abyssal plain sediments characterized by rock-magnetic and geochemical indices, Mar. Geol., 163, 77-107, doi:10.1016/S0025-3227(99)00108-5.

Rowan, C. J., A. P. Roberts, and T. Broadbent (2009), Reductive diagenesis, magnetite dissolution, greigite growth and paleomagnetic smoothing in marine sediments: A new view, Earth Planet. Sci. Lett., 277, 223-235, doi:10.1016/ j.eps1.2008.10.016.

Sahota, J. T. S., S. G. Robinson, and F. Oldfield (1995), Magnetic measurements used to identify paleoxidation fronts in deep-sea sediments from the Madeira Abyssal Plain, Geophys. Res. Lett., 22, 1961-1964, doi:10.1029/95GL01798.

Schlitzer, R. (2012), Ocean Data View. [Available at http:// odv.awi.de.]

Schoonen, M. A. A., and H. L. Barnes (1991), Mechanisms of pyrite and marcasite formation from solution: III. Hydrothermal processes, Geochim. Cosmochim. Acta, 55, 34913504, doi:10.1016/0016-7037(91)90050-F.

Schulz, H., U. von Rad, and H. Erlenkeuser (1998), Correlation between Arabian Sea and Greenland climate oscillations of the past 110,000 years, Nature, 393, 54-57, doi:10.1038/31750.

Sirocko, F., M. Sarnthein, H. Erlenkeuser, H. Lange, M. Arnold, and J. C. Duplessy (1993), Century-scale events in monsoonal climate over the past 24,000 years, Nature, 364, 322-324, doi:10.1038/364322a0.

Snowball, I. F. (1993), Geochemical control of magnetite dissolution in sub-arctic lake sediments and the implications for environmental magnetism, J. Quat. Sci., 8, 339-346, doi:10.1002/jqs.3390080405.

Southon, J., M. Kashgarian, M. Fontugne, B. Metivier, and W. W. S. Yim (2002), Marine reservoir corrections for the Indian Ocean and Southeast Asia, Radiocarbon, 44, 167-180.

Stanford, J. D., E. J. Rohling, S. Bacon, A. P. Roberts, F. E. Grousset, and M. Bolshaw (2011), A new concept for the paleoceanographic evolution of Heinrich event 1 in the North Atlantic, Quat. Sci. Rev., 30, 1047-1066, doi:10.1016/j.quascirev.2011.02.003. 
Stein, M., A. Almogi-Labin, S. L. Goldstein, C. Hemleben, and A. Starinsky (2007), Late Quaternary changes in desert dust inputs to the Red Sea and Gulf of Aden from ${ }^{87} \mathrm{Sr} /{ }^{86} \mathrm{Sr}$ ratios in deep-sea cores, Earth Planet. Sci. Lett., 261, 104119, doi:10.1016/j.epsl.2007.06.008.

Stuiver, M., and P. J. Reimer (1993), Extended ${ }^{14} \mathrm{C}$ data base and revised calib 3.0 14C age calibration program, Radiocarbon, 35, 215-230.

Sweeney, R. E., and I. R. Kaplan (1973), Pyrite framboid formation: Laboratory synthesis and marine sediments, Econ. Geol., 68, 618-634, doi:10.2113/gsecongeo.68.5.618.

Tarduno, J. A. (1992), Magnetic susceptibility cyclicity and magnetic dissolution in Cretaceous limestones of the Southern Alps (Italy), Geophys. Res. Lett., 19, 1515-1518, doi:10.1029/92GL01484.

Thompson, R., and F. Oldfield (1986), Environmental Magnetism, 227 pp., Allen and Unwin, London.

Thouveny, N., E. Moreno, D. Delanghe, L. Candon, Y. Lancelot, and N. J. Shackleton (2000), Rock magnetic detection of distal ice-rafted debries: clue for the identification of Heinrich layers on the Portuguese margin, Earth Planet. Sci. Lett., 180, 61-75, doi:10.1016/S0012-821X(00)00155-2. van der Zee, C., D. R. Roberts, D. G. Rancourt, and C. P. Slomp (2003), Nanogoethite is the dominant reactive oxyhydroxide phase in lake and marine sediments, Geology, 31, 993-996, doi:10.1130/G19924.1.

van Weering, T. C. E., W. Helder, and P. Schalk (1997), The Netherlands Indian Ocean Expedition 1992-1993, first results and an introduction, Deep Sea Res., Part II, 44, 1177-1193.

von Rad, U., H. Schulz, V. Riech, M. den Dulk, U. Berner, and F. Sirocko (1999), Multiple monsoon-controlled breakdown of oxygen-minimum conditions during the past 30,000 years documented in laminated sediments off Pakistan, Palaeogeogr. Palaeoclimatol. Palaeoecol., 152, 129-161, doi:10.1016/S00310182(99)00042-5.

Weeks, R., C. Laj, L. Endignoux, M. Fuller, A. Roberts, R. Manganne, E. Blanchard, and W. Goree (1993), Improvements in long-core measurement techniques: applications in palaeomagnetism and palaeoceanography, Geophys. J. Int., 114, 651-662, doi:10.1111/j.1365-246X.1993.tb06994.x.

Wilkin, R. T., and H. L. Barnes (1997), Formation processes of framboidal pyrite, Geochim. Cosmochim. Acta, 61, 323339, doi:10.1016/S0016-7037(96)00320-1. 